Review

\title{
Zoonotic Significance and Antimicrobial Resistance in Salmonella in Poultry in Bangladesh for the Period of 2011-2021
}

\author{
Md. Jannat Hossain ${ }^{1,2}$, Youssef Attia ${ }^{3, *(\mathbb{D})}$, Fatimah Muhammad Ballah ${ }^{2}$, Md. Saiful Islam ${ }^{2}{ }^{\mathbb{D}}$, Md. Abdus Sobur $^{2}{ }^{(0)}$, \\ Md. Amirul Islam ${ }^{2}$, Samina Ievy ${ }^{2}$, Asadur Rahman ${ }^{4}$, Akira Nishiyama ${ }^{4}$, Md. Shafiqul Islam ${ }^{2}$, \\ Jayedul Hassan ${ }^{2}\left(\mathbb{D}\right.$ and Md. Tanvir Rahman ${ }^{2, *} \mathbb{0}$
}

check for

updates

Citation: Hossain, M.J.; Attia, Y.; Ballah, F.M.; Islam, M.S.; Sobur, M.A.; Islam, M.A.; Ievy, S.; Rahman, A.; Nishiyama, A.; Islam, M.S.; et al. Zoonotic Significance and

Antimicrobial Resistance in Salmonella in Poultry in Bangladesh for the Period of 2011-2021. Zoonotic Dis. 2021, 1, 3-24. https://doi.org/ $10.3390 /$ zoonoticdis 1010002

Academic Editor: Seiya Yamayoshi

Received: 19 July 2021

Accepted: 7 September 2021

Published: 30 November 2021

Publisher's Note: MDPI stays neutral with regard to jurisdictional claims in published maps and institutional affiliations.

Copyright: (c) 2021 by the authors. Licensee MDPI, Basel, Switzerland. This article is an open access article distributed under the terms and conditions of the Creative Commons Attribution (CC BY) license (https:/ / creativecommons.org/licenses/by/ $4.0 /)$.
1 Department of Microbiology and Public Health, Faculty of Veterinary, Animal and Biomedical Sciences, Khulna Agricultural University, Khulna 9100, Bangladesh; jannat@kau.edu.bd

2 Department of Microbiology and Hygiene, Faculty of Veterinary Science, Bangladesh Agricultural University, Mymensingh 2202, Bangladesh; moncher.ballah13@gmail.com (F.M.B.); dvm41257@bau.edu.bd (M.S.I.); soburvetbau@gmail.com (M.A.S.); amirulmicrobau@gmail.com (M.A.I.); v.samina@gmail.com (S.I.); shafiq_micro@bau.edu.bd (M.S.I.); dr_jahid@bau.edu.bd (J.H.)

3 Department of Agriculture, Faculty of Environmental Sciences, King Abdulaziz University, P.O. Box 80208, Jeddah 21589, Saudi Arabia

4 Department of Pharmacology, Faculty of Medicine, Kagawa University, 1750-1 Ikenobe, Miki-cho 761-0793, Japan; rahman.md.asadur@kagawa-u.ac.jp (A.R.); nishiyama.akira@kagawa-u.ac.jp (A.N.)

* Correspondence: yaattia@kau.edu.sa (Y.A.); tanvirahman@bau.edu.bd (M.T.R.)

Abstract: Antimicrobial resistance (AMR) in Salmonella in poultry poses a serious human health threat as it has zoonotic importance. Poultry is often linked with outbreaks of Salmonella-associated foodborne illness. Since antimicrobials are heavily used in poultry in Bangladesh, multidrug-resistant (MDR) Salmonella is quite frequently found there. MDR Salmonella is challenging to treat with antimicrobials and often causes a severe economic loss in the poultry sector. By horizontal gene transfer and/or evolutionary mutations, antimicrobials primarily exert selection pressure that contributes to antimicrobials resistance. In addition, resistance patterns can vary with variations in time and space. Without having prior knowledge of resistance patterns, no effective drugs could be prescribed. Therefore, it is crucial to have updated knowledge on the status of AMR in Salmonella in Bangladesh for effective treatment and management of the flocks against salmonellosis. There are several review articles on AMR in Salmonella in poultry in Bangladesh; they lack the whole scenario of the country and particularly do not have enough data on the poultry environment. Considering this scenario, in this review, we have focused on AMR in Salmonella in poultry in Bangladesh (2011-2021), with particular emphasis on data from the poultry and farm environments on a divisional zone basis.

Keywords: AMR; Salmonella; poultry; zoonotic; antimicrobials; Bangladesh; MDR; resistance; environment

\section{Introduction}

The poultry sector has turned into a symbol of a profitable business among the people of Bangladesh [1]. Reports from the Department of Livestock Services (DLS) denote that the poultry population in Bangladesh is more than 350 million, contributing to the advancement of the national economy and employment generation [2]. In addition, the poultry sector provides cheaper and easily reachable sources of nutrition and protein in terms of egg and meat to all classes of people [3]. The poultry sector contributes almost $40 \%$ of the total meat supply and more than $25 \%$ of Bangladesh's total human protein demands [4,5]. Furthermore, this sector has shown adequate support to the nation in gaining the sustainable development goals (SDGs) of eliminating malnourishment and securing improved health by supplying protein-containing foods. However, the poultry sector is attacked regularly with the introduction of bacterial infections. Salmonellosis is one of them. Many serovars of the genus Salmonella under the Enterobacteriaceae family are responsible for salmonellosis [6]. In the chicken business, salmonellosis is amongst the most dangerous bacterial infections, resulting in significant financial loss due 
to death and reduced productivity $[7,8]$. Salmonellosis also causes pullorum disease, fowl typhoid and other contaminations developed from poultry herds (intense systemic malady and gastrointestinal issues) to incubator (embryonic issue) [9]. The genus of Salmonella is isolated into two species: S. enterica and S. bongori; among them, S. enterica can cause devastating consequences. Serovars Typhimurium and Enteritidis of Salmonella enterica are the common causes of salmonellosis. Infantis is a serovar that affects people all around the world [10]. More than 20 million humans and animals are infected with Salmonella each year. It decreases animal productivity and causes 150,000 human and animal fatalities each year [10]. Typhoid infection is most common in the south-central and south-east Asian regions (more than 100/100,000 people per year) [10].

AMR has become a severe global challenge by affecting all health components [11,12]. It is assumed that AMR problem will cause hundreds of millions of human deaths along with severe financial crisis and severe damage in livestock productions by $2050[13,14]$. Furthermore, the consequences will be disastrous for low and middle earnings countries, such as Bangladesh [15]. The AMR attributes a threatening situation in food security by developing production losses in the poultry sector. A global action plan (GAP) with a "one health" approach has been put in place by the World Health Organization (WHO) to fight against the emerging global threat in an extensive system. Recently, Bangladesh has developed a national action plan that aligns with AMR-oriented GAP rules [16-18].

For simple cases of salmonellosis (watery diarrhea), antimicrobial agents are not recommended. Antimicrobials are usually administered for severe cases of salmonellosis, and also for typhoid fever. However, antimicrobials resistance in Salmonella is becoming a major threat for the public health around the globe. Human activity has contaminated the poultry farm environment (air, water and soil) with antimicrobial residues and resistant organisms [19]. The elevation of antimicrobial-resistant Salmonella is connected in many cases with the haphazard use of antimicrobials in poultry farming. Salmonella has become less susceptible to different kinds of antimicrobials in poultry farming because of their indiscriminate use therefore it develops treatment failure [20-22]. Salmonellosis is a significant threat to poultry farming in Bangladesh by causing severe economic losses every year. It has become more devastating due to the AMR. The mortality rate in poultry due to antimicrobial-resistant Salmonella is much higher than that of infections due to non-antimicrobial-resistant Salmonella strains. In this case, it is pivotal to have an adequate idea of antimicrobial-resistant Salmonella in poultry farming. Nevertheless, there is no sufficient review data on antimicrobial-resistant Salmonella in poultry in Bangladesh in recent years. The purpose was to give references for future work as well as a request to intervene in the AMR by implementing a One Health program.

\section{Materials and Methods}

We used PubMed, Web of Science, Google Scholar, ResearchGate and Crossref databases to perform a written survey on the AMR Salmonella situation in Bangladesh's poultry health division and around the world. To begin with, we centered the primary segment on the foundation of AMR Salmonella circumstance around the world, its impacts on poultry and open wellbeing segments, the potential source of AMR in poultry and present patterns in antimicrobial utilization in Bangladesh.

Keywords used to search databases were "AMR Salmonella situations in poultry from 2010 to 2021 in Bangladesh" and "AMR Salmonella in different divisions of Bangladesh;" "AMR Salmonella organisms in poultry production of Bangladesh;" "Antibiotic-resistant" or "antimicrobial-resistant" in poultry farm environment in Bangladesh". Antimicrobial resistance in Salmonella in Bangladesh chickens was the subject of all key discoveries from studies conducted between 2011 and 2021. The AMR situation in individuals, agribusiness, aquaculture or banned scenarios that were supposed to be unimportant to the display were investigated in this study. The major findings connected to this study (initial writers, launched period, poultry ranch category with geographic area, sample type, array of resistance with antimicrobial groups and resistance genes) were extracted from the papers in Table 1. 
Table 1. Major findings of studies (2011-2021) focused on antimicrobial resistance in Salmonella in poultry in Bangladesh.

\begin{tabular}{|c|c|c|c|c|c|c|c|c|}
\hline $\begin{array}{l}\text { Study Year/Study } \\
\text { Location }\end{array}$ & $\begin{array}{l}\text { Sample } \\
\text { Category }\end{array}$ & $\begin{array}{l}\text { Sample } \\
\text { Size }\end{array}$ & Sample Type & $\begin{array}{l}\text { Isolation Method } \\
\text { Culture/Confirm } \\
\text { by PCR }\end{array}$ & Resistance Phenotype & $\begin{array}{l}\text { Detection Disk Dif- } \\
\text { fusion/Genotype } \\
\text { by PCR }\end{array}$ & $\begin{array}{l}\text { Resistance } \\
\text { Genotype }\end{array}$ & References \\
\hline 2010/Dhaka & Layer & 100 & Egg surface & Culture & $\begin{array}{l}\text { Amoxicillin }(87.50 \%), \text { Ampicillin }(87.50 \%) \text {, Erythromycin } \\
(62.50 \%) \text {, Cephalexin (50\%), Doxycycline }(50 \%) \\
\text { Ceftazidime }(37.50 \%), \text { Nalidixic acid }(25 \%)\end{array}$ & Disk diffusion & - & [23] \\
\hline 2008-2010/Dhaka & Layer & 300 & $\begin{array}{l}\text { Cloacal swab, } \\
\text { intestinal fluid, egg } \\
\text { surface, hand wash } \\
\text { and soil }\end{array}$ & Culture & $\begin{array}{c}\text { Penicillin (100\%), Tetracycline (100\%), Erythromycin }(82 \%) \text {, } \\
\text { Ampicillin }(88 \%) \text {, Rifampicin (60\%), Cephalexin }(65 \%), \\
\text { Chloramphenicol (58\%), Cefixine (50\%), Norfloxacin }(20 \%) \text {, } \\
\text { Ciprofloxacin (20\%), Nalidixic acid (20\%) }\end{array}$ & Disk diffusion & - & [24] \\
\hline 2011/Mymensingh & Broiler & 60 & $\begin{array}{l}\text { Dressing water, } \\
\text { devices and } \\
\text { environmental } \\
\text { swabs }\end{array}$ & Culture & $\begin{array}{c}\text { Ampicillin (100\%), Chloramphenicol }(100 \%) \text {, Streptomycin } \\
(100 \%), \text { Nalidixic acid }(100 \%), \text { Tetracycline }(100 \%), \\
\text { Erythromycin }(100 \%), \text { Azithromycin }(81.25 \%), \\
\text { Gentamicin }(81.25 \%)\end{array}$ & Disk diffusion & - & [25] \\
\hline 2009-2010/Savar & Layer & 67 & Poultry samples & Culture/PCR & $\begin{array}{c}\text { Rifampicin (88\%), Clindamycin (84\%), Oxacillin ( } 84 \%), \\
\text { Vancomycin (78\%), Doxycycline (52\%), Levofloxacin }(50 \%) \text {, } \\
\text { Azithromycin ( } 25 \%) \text {, Ceftriaxone }(10 \%)\end{array}$ & Disk diffusion/PCR & - & [26] \\
\hline 2012/Chittagong & Layer & 30 & Dead birds & Culture & $\begin{array}{c}\text { Amoxicillin }(100 \%) \text {, Tetracycline }(100 \%) \text {, Enrofloxacin } \\
(87.50 \%) \text {, Ciprofloxacin }(87.50 \%), \text { Pefloxacin }(87.50 \%), \\
\text { Doxycycline }(50 \%) \text {, Colistin }(50 \%), \\
\text { Kanamycin }(50 \%)\end{array}$ & Disk diffusion & - & [27] \\
\hline 2014/Mymensingh & Broiler & 50 & Cloacal swabs & Culture/PCR & $\begin{array}{c}\text { Amoxicillin }(87.50 \%), \\
\text { Cloxacillin }(87.50 \%) \text {, Erythromycin }(87.50 \%) \text {, Colistin } \\
(50 \%) \text {, Ciprofloxacin }(31.25 \%)\end{array}$ & Disk diffusion/PCR & - & [28] \\
\hline $\begin{array}{l}\text { 2015/Mymensingh, } \\
\text { Gazipur and Sherpur }\end{array}$ & Broiler & 60 & $\begin{array}{l}\text { Dressed broiler } \\
\text { carcass }\end{array}$ & Culture/PCR & $\begin{array}{c}\text { Amoxicillin }(82 \%) \text {, Erythromycin }(82 \%), \\
\text { Tetracycline }(68 \%) \text {, Streptomycin }(38 \%), \\
\text { Azithromycin }(22 \%)\end{array}$ & Disk diffusion/PCR & - & [29] \\
\hline 2013/Chittagong & Layer & 310 & $\begin{array}{l}\text { Eggs, egg surface, } \\
\text { and trays }\end{array}$ & Culture & $\begin{array}{c}\text { Ampicillin (100\%), Amoxicillin (100\%), Erythromycin } \\
(90 \%) \text {, Tetracycline ( } 94.50 \%) \text {, Ciprofloxacin }(49.50 \%), \\
\text { Colistin (60\%), } \\
\text { Enrofloxacin }(60 \%) \text {, Pefloxacin }(12.50 \%)\end{array}$ & Disk diffusion & - & {$[30]$} \\
\hline 2015/Mymensingh & Layer & 150 & $\begin{array}{l}\text { Droppings and } \\
\text { Cloacal swabs }\end{array}$ & Culture/PCR & $\begin{array}{l}\text { 81.81\% isolates were resistant to Amoxicillin, Doxycycline, } \\
\text { Kanamycin, Gentamicin, and Tetracycline and } 45.46 \% \\
\text { isolates to Ciprofloxacin }\end{array}$ & Disk diffusion/PCR & - & [31] \\
\hline 2012/Mymensingh & Layer & 60 & $\begin{array}{l}\text { Cloacal swabs, } \\
\text { intestinal fluid, egg } \\
\text { surface, feces, air } \\
\text { and hand washings }\end{array}$ & Culture & $\begin{array}{c}\text { Erythromycin }(100 \%), \text { Tetracycline }(100 \%), \text { Nalidaxic Acid } \\
(100 \%) \text { and } 40 \% \text { to Ampicillin, Amoxicillin, } \\
\text { Sulfamethoxazole, Kanamycin and Chloramphenicol }\end{array}$ & Disk diffusion & - & [32] \\
\hline
\end{tabular}


Table 1. Cont.

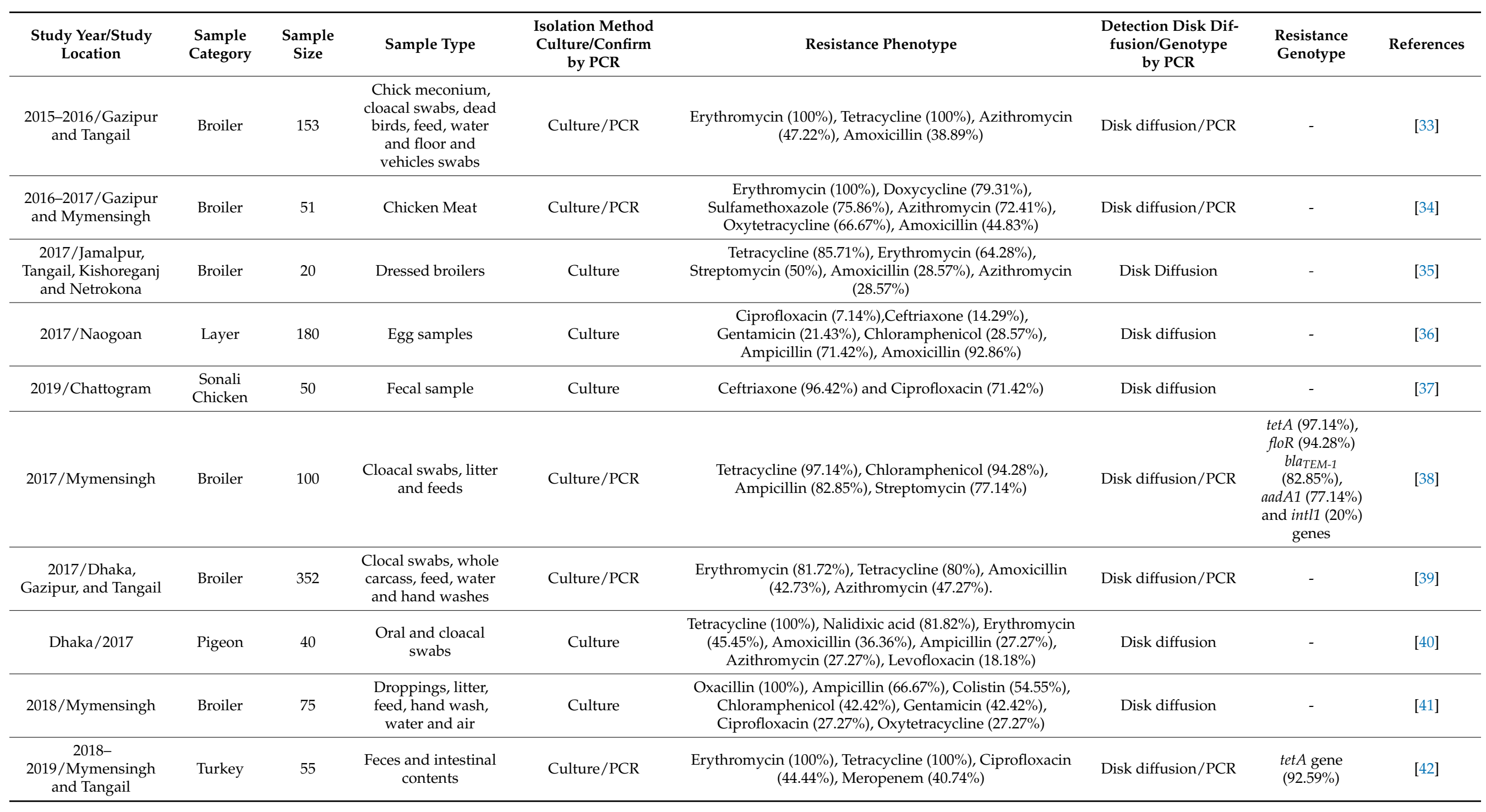


Table 1. Cont.

\begin{tabular}{|c|c|c|c|c|c|c|c|c|}
\hline $\begin{array}{l}\text { Study Year/Study } \\
\text { Location }\end{array}$ & $\begin{array}{l}\text { Sample } \\
\text { Category }\end{array}$ & $\begin{array}{l}\text { Sample } \\
\text { Size }\end{array}$ & Sample Type & $\begin{array}{l}\text { Isolation Method } \\
\text { Culture/Confirm } \\
\text { by PCR }\end{array}$ & Resistance Phenotype & $\begin{array}{l}\text { Detection Disk Dif- } \\
\text { fusion/Genotype } \\
\text { by PCR }\end{array}$ & $\begin{array}{l}\text { Resistance } \\
\text { Genotype }\end{array}$ & References \\
\hline $\begin{array}{l}\text { 2019/Dhaka, Sylhet, } \\
\text { Mymensingh, } \\
\text { Chattogram, and } \\
\text { Rajshahi }\end{array}$ & Broiler & 113 & $\begin{array}{l}\text { Frozen Chicken } \\
\text { Meat Sample }\end{array}$ & Culture/PCR & $\begin{array}{l}\text { Oxytetracycline }(100 \%) \text {, Sulfamethoxazole }(89.20 \%), \\
\text { Tetracycline }(86.50 \%), \text { Nalidixic acid }(83.80 \%), \text { Amoxicillin } \\
(74.30 \%), \text { Pefloxacin }(70.30 \%) \text {, Imipenem }(48.60 \%)\end{array}$ & Disk diffusion/PCR & $\begin{array}{c}b l a_{\mathrm{CTX}-\mathrm{M}-1} \\
(2.7 \%), \\
b l a_{\mathrm{NDM}-1} \\
(20.3 \%), q n r A \\
(4.1 \%) \text { and } \\
q n r S(6.8 \%) \\
\text { genes }\end{array}$ & [43] \\
\hline 2016/Rajshahi & $\begin{array}{l}\text { Broiler } \\
\text { and Layer }\end{array}$ & 120 & Cloacal swabs & Culture & $\begin{array}{l}\text { Penicillin (100\%), Nalidixic acid (100\%), Sulfamethoxazole } \\
(55 \%) \text {, Ampicillin }(40 \%) \text {, Amoxicillin }(25 \%)\end{array}$ & Disk diffusion & - & [45] \\
\hline $\begin{array}{l}\text { 2018- } \\
\text { 2019/Mymensingh, } \\
\text { Jamalpur }\end{array}$ & Broiler & 70 & $\begin{array}{l}\text { Feces, meatand } \\
\text { visceral organ }\end{array}$ & Culture/PCR & $\begin{array}{l}\text { Amoxicillin }(100 \%) \text {, Tetracycline }(90.48 \%) \text {, Ceftazidime } \\
(61.90 \%) \text {, Chloramphenicol }(38.10 \%) \text { and Colistin }(33.33 \%)\end{array}$ & Disk diffusion/PCR & - & [46] \\
\hline 2019/Dhaka & $\begin{array}{l}\text { Broiler, } \\
\text { Sonali and } \\
\text { Native }\end{array}$ & 870 & Cecal contents & Culture/PCR & $\begin{array}{l}\text { 100\% to Ciprofloxacin, Streptomycin and Tetracycline. } \\
86.70 \% \text { to Nalidixic acid and Gentamicin. Ampicillin } \\
(72.70 \%), 20 \% \text { to Amoxicillin, Chloramphenicol, } \\
\text { Sulfamethoxazole, Cefixime and Ceftriaxone }\end{array}$ & Disk diffusion/PCR & $\begin{array}{l}\text { bla } a_{\mathrm{TEM}}(73.3 \%), \\
\text { tetA }(100 \%), \\
\text { sul1 }(80.2 \%) \\
\text { and strA/B } \\
(33.3 \%) \text { genes }\end{array}$ & [47] \\
\hline $\begin{array}{l}\text { 2020/Dhaka, } \\
\text { Mymensingh, } \\
\text { Rangpur, Sylhet, and } \\
\text { Chattogram }\end{array}$ & Layer & 765 & $\begin{array}{l}\text { Cloacal swabs (535), } \\
\text { visceral organs (50), } \\
\text { and droppings (180) }\end{array}$ & Culture/PCR & $\begin{array}{c}\text { Amoxicillin }(49.70 \%), \text { Sulfamethoxazole }(47.70 \%), \\
\text { Erythromycin }(43.70 \%), \text { Azithromycin }(31 \%), \\
\text { Oxytetracycline }(79.70 \%) \text {, Doxycycline }(61.40 \%), \\
\text { Ciprofloxacin }(30 \%) \text {, Gentamicin }(32 \%)\end{array}$ & Disk diffusion/PCR & - & [48] \\
\hline
\end{tabular}




\section{Salmonellosis in Poultry}

Salmonellosis having zoonotic potentiality could be frequently detected in poultry flocks [49]. Salmonellosis can be contracted by eating contaminated, unsanitary food contaminated with Salmonella. In the summer, the sickness is more common than in the winter [50]. Salmonellosis could be a common illness in numerous developing nations, counting Bangladesh [51]. Salmonella contamination restricts the production of poultry in Bangladesh. Multidrug-resistant Salmonella is a significant threat for this poultry across the globe, including Bangladesh [26]. In addition, Salmonella can be a widespread food-borne pathogen with serious consequences for public health [52]. Salmonella from chickens can transmit to humans through contaminated meat and crude eggs. In Bangladesh, where medium-sized economic ranches are dominant, salmonellosis is spreading at the farm holding level [53].

Salmonella is one of the most serious concerns for Bangladesh's poultry sector, with significant public health implications [54]. The infection pullorum is caused by $S$. Pullorum which is passed down vertically from parent to descendent [55]. Salmonella Gallinarum causes fowl typhoid, is a serious or persistent infection that typically affects older chickens, providing a substantial rate of death and lowering reproductive performance. Furthermore, $S$. Gallinarum can cause damage to newborns that is different from that caused by pullorum disease [56].

Clinical signs of fowl typhoid include increased risk of death and inferior quality in chicks born from contaminated eggs, which are typical of a septicemic infection in poultry. Anemia, sadness, labored breathing, and diarrhea in older birds cause excrement to cling on the vent. Pullorum disease has the highest fatality rate in 2-3-week-old birds. The sickness may be minor or undetectable in older birds. Susceptibility increases at the point of lay in both breeding and laying flocks [57]; however, pullorum disease may have no symptoms other than decreased egg production and hatchability. Among the most important transmission channels for illnesses is trans-ovarian infection, which causes infection of the egg and newborn chicks or poults [58]. Reported antimicrobial resistance in Salmonella in different divisions of Bangladesh is presented in Figure 1.

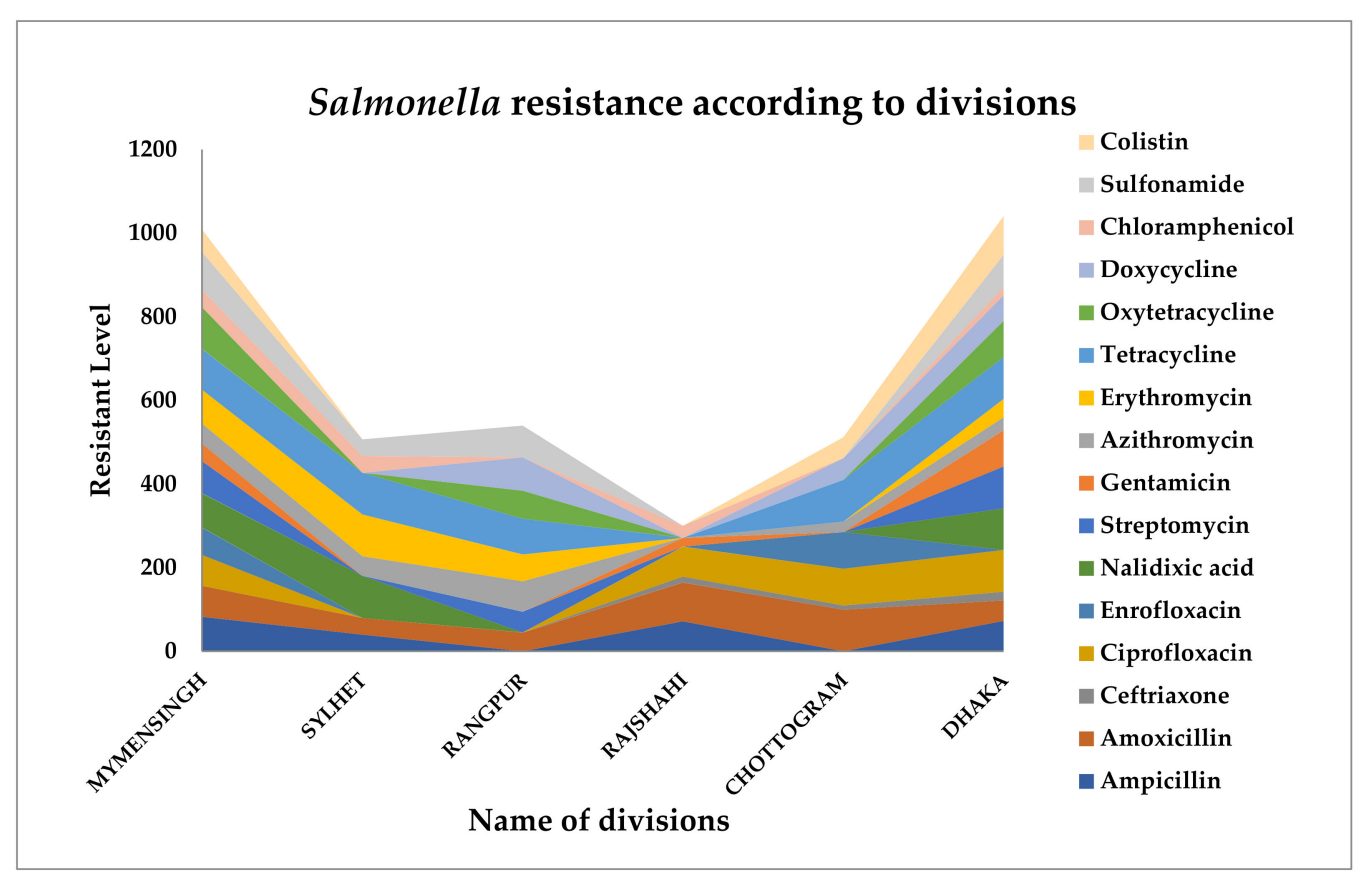

Figure 1. Antimicrobial resistance profiles of Salmonella in poultry in different divisions of Bangladesh. 


\section{Transmission of Salmonella}

Salmonella is widely dispersed and survives in arid conditions, although it may survive for months in water. Salmonella enterica can cause both human and animal illnesses [59]. Salmonella can induce clinical or sub-clinical infection in symptomless animals that are called "carriers". Salmonella can continually and routinely be excreted in feces from these carrier birds to contaminate the surrounding environment without clinical symptoms. Salmonella can transmit both horizontally and vertically [59].

In Salmonella contamination in chickens induced by serovar Enteritidis with a unique preference for the chicken reproduction cycle, vertical transmission is of particular concern. In this situation, transovarian contamination occurs when the mother fowl is exposed to systemic contamination, which causes ovarian illness and egg production within the oviduct [60]. Serovar Enteritidis contaminates eggs in part due to microbes moving from the cloaca to regenerative organs [60]. Aerosol or fecal transfer may occur. Salmonella can be spread through fomite, polluted drinking water, infected food and filthy cages [61,62].

A few of the salmonellosis outbreak trials were kept separate from those that used live chickens, and there was also some indirect contact with contaminated food vendors [63]. A foodborne illness spread by handlers infected by direct contact with farm chickens is another example of an epidemic caused by indirect contact with live poultry $[64,65]$. Possible transmission routes of salmonellosis in poultry in Bangladesh are presented in Figure 2.

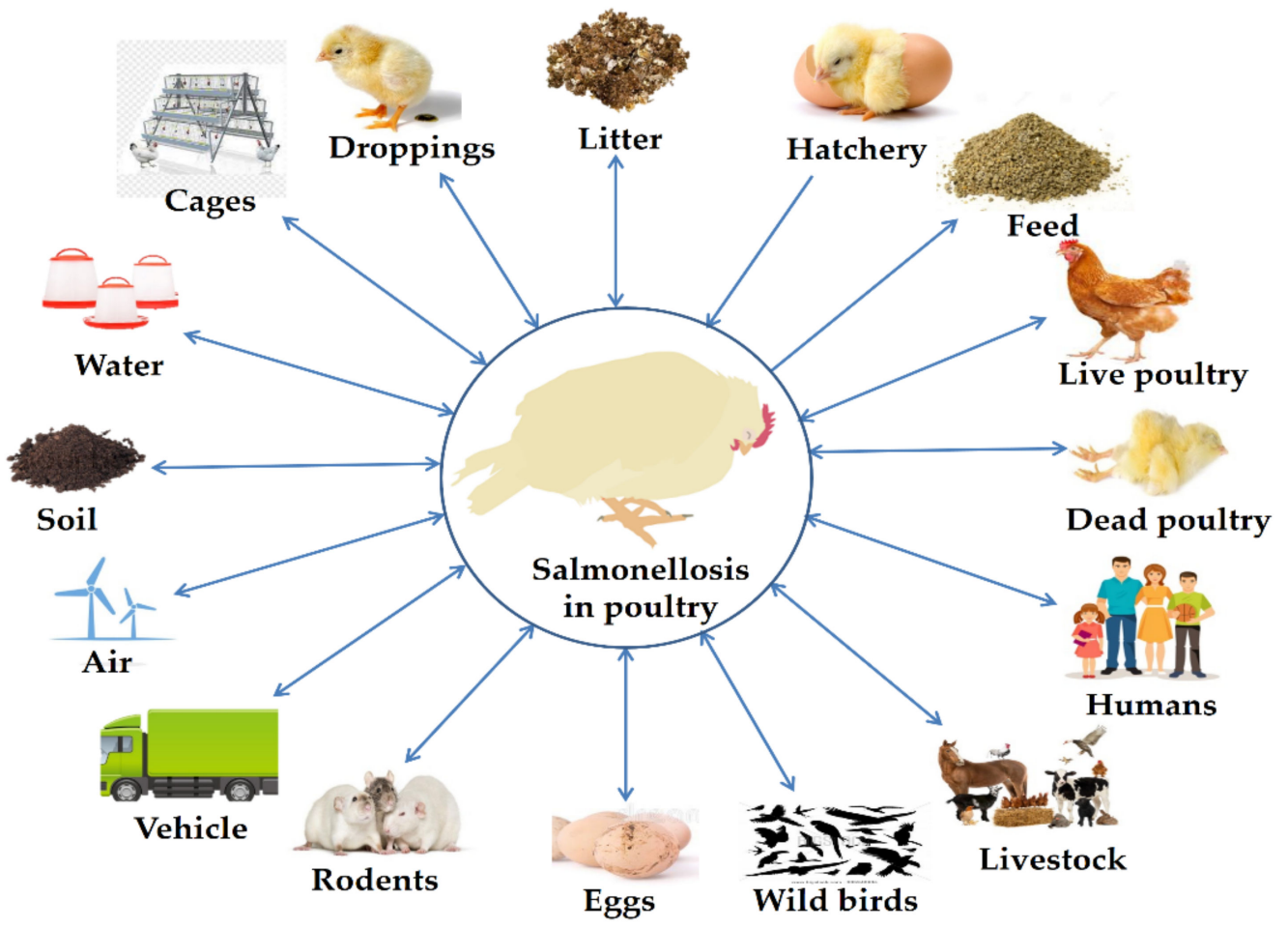

Figure 2. Possible transmission routes of salmonellosis in poultry in Bangladesh.

\section{Zoonotic Importance of Salmonella}

Salmonella is a major zoonotic pathogen. It is responsible for severe economic losses and also has a public health concern. Most common Salmonella enterica serovars in humans and animals are listed in Table 2. 
Table 2. Most common Salmonella enterica serovars had seen in humans and animals (Adapted from [66]).

\begin{tabular}{|c|c|c|c|}
\hline Host. & Serovars & Major Symptoms & Zoonotic Importance \\
\hline \multirow{4}{*}{ Human } & $\begin{array}{c}\text { Salmonella enterica serovar } \\
\text { Typhi (S. Typhi) }\end{array}$ & Typhoid fever & Yes \\
\hline & $\begin{array}{l}\text { Salmonella enterica serovar } \\
\text { Paratyphi (S. Paratyphi) }\end{array}$ & Paratyphoid fever & Yes \\
\hline & S. Typhimurium & $\begin{array}{c}\text { Non-typhoidal } \\
\text { Salmonellosis/Enteritis }\end{array}$ & Yes \\
\hline & S. Enteritidis & $\begin{array}{c}\text { Non-typhoidal } \\
\text { Salmonellosis/Enteritis }\end{array}$ & Yes \\
\hline \multirow{4}{*}{ Poultry } & S. Gallinarum & Fowl typhoid & Yes \\
\hline & S. Pullorum & Pullorum disease & Yes \\
\hline & S. Typhi & Salmonellosis & Yes \\
\hline & S. Enteritidis & Salmonellosis & Yes \\
\hline Ducks & S. Anatum & Keel disease & Yes \\
\hline \multirow{3}{*}{ Sheep and goats } & S. Abortusovis & Salmonellosis & Yes \\
\hline & S. Anatum & Salmonellosis & Yes \\
\hline & S. Montevideo & Salmonellosis & Yes \\
\hline \multirow{3}{*}{ Cattle } & S. Dublin & Salmonellosis & Yes \\
\hline & S. Typhimurium & Salmonellosis & Yes \\
\hline & S. Newport & Salmonellosis & Yes \\
\hline \multirow{3}{*}{ Horses } & S. Anatum & Salmonellosis & Yes \\
\hline & S. Agona & Salmonellosis & Yes \\
\hline & S. Enteritidis & Salmonellosis & Yes \\
\hline
\end{tabular}

Salmonella can be transmitted from animals to people, as well as the other way around. Infection spreads from animals to people most commonly through contaminated food. Contaminated meat and eggs, as well as contaminated lettuce and other leafy vegetables, sprouts, spices and seeds, are also potential sources of infection. Contact with infected persons is another source of infection [67].

The infectious dosage of Salmonella is relatively high; however, it varies with the strain characteristics, age and immune status of the individual. A healthy adult with a normal immune system needs up to 100,000 bacteria to become unwell. On the other hand, too little bacteria can make children or the elderly unable to resist the disease. Salmonellosis has a 1-3-day incubation period ( $6 \mathrm{~h}$ to 10 days) [68].

The disease outcomes also vary with the age and immune status of the individual. It usually causes dehydration as a result of diarrhea, nausea and vomiting. Fever is also fairly common. In immune-compromised persons, it can progress to septicemia or localized infection. Although the disease usually does not cause mortality in humans, the costs incurred as a result of the condition are often staggering. It has the potential to kill vulnerable people, such as infants, the aged and those with impaired immune systems [69].

\section{Overall Prevalence of Salmonella}

Poultry appears to be a general reservoir of Salmonella [70]. Salmonella contamination at an increased level is concerning for both poultry farming and public health. Since the egg surface may have been contaminated with Salmonella via excrement during lay in an unsanitary environment from tainted fowl, the average Salmonella content is $18.09 \%[23,30,32,36]$. In this review, we found that $17.19 \%, 28.57 \%$ and $30 \%$ of salmonellae were present in water, transport swab and air samples from poultry farm environments 
in Bangladesh $[25,33,39,41]$. This study also observed that average $26.30 \%$ of the cloacal swab samples, $42 \%$ of the visceral organ samples and $60 \%$ of intestinal fluid samples were infected with Salmonella $[24,32,38,44,45,48]$. Salmonella infection in poultry farm samples has been documented from many regions of the world, with rates of $17 \%, 35 \%, 36 \%$, $39 \%$ and $53 \%$ in the United States, Spain, Korea, Brazil and Vietnam, respectively [71,72]. Salmonella was found in $23.44 \%$ of poultry handlers, indicating a possible breakdown in personal hygiene during bird handling and shipment of chicken products [24,32,39,41]. Poultry droplets and litters in various chicken farms in Bangladesh were found to contain an average of $26 \%$ and $25.71 \%$ Salmonella, respectively [31,38,41]. Commercial poultry feed should be free from Salmonella but average $18.75 \%$ Salmonella was found within poultry feeds in different farms due to accidental contamination with feces or litter [33,38,41]. Locally processed fish by-products were a substantial source of bacterial contamination of chicken feeds among the animal protein sources and common ingredients of poultry feed. Salmonella has also been found in feed and feeding materials of poultry and animals as a natural microflora [73]. Figure 3 shows the total prevalence of Salmonella in poultry, feed farm components, etc. in Bangladesh by sample types.

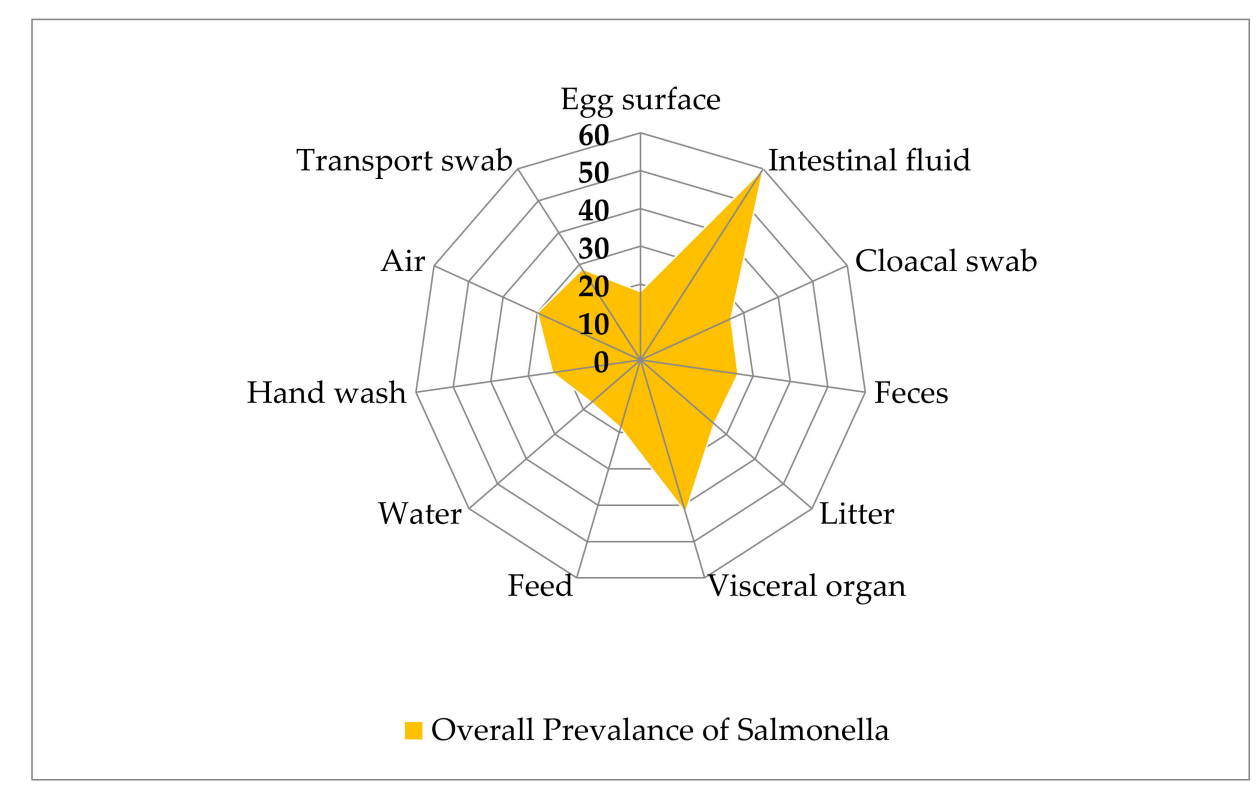

Figure 3. Samples wise overall prevalence of Salmonella in poultry in Bangladesh.

\section{Antimicrobial Resistance Profile of Salmonella}

\subsection{Resistance to Penicillins}

Penicillins are antimicrobials that are classified as $\beta$-lactams [74]. Ampicillin, amoxicillin, oxacillin and cloxacillin are broadly utilized semi-synthetic antimicrobials within the penicillin class.

Akond et al. [24] reported 100\% penicillin-resistant and $88 \%$ ampicillin-resistant Salmonella in hand wash, intestinal fluid, cloacal swab, egg surface and soil samples from a layer farm in Dhaka. Sarker et al. [45] reported similar results ten years later, both in broilers and layers in Rajshahi. Ampicillin was the first broad-spectrum antibiotic of the penicillin group. Ahmed et al. [23] reported that $87.50 \%$ of Salmonella exhibited resistance to ampicillin and amoxicillin in egg surface samples from laying hens at different markets in Dhaka city. Additionally, Mahmud et al. [30] and Talukder et al. [46] observed 100\% resistance to ampicillin and amoxicillin in Chittagong and Mymensingh. Furthermore, Salmonella was found to be $40 \%$ to $92.86 \%$ resistant to ampicillin and amoxicillin in broilers and layers [32,34,36,48]. Jahan et al. [25] detected 100\% ampicillin- and amoxicillin-resistant Salmonella from dressed broilers, water and device surface samples, whereas Alam et al. [38] and Hossain et al. [41] reported $66.67 \%$ to $82.85 \%$ ampicillin-resistant Salmonella in cloacal, 
fecal, litter, feed, water, air and handwashing samples collected from different broiler farms in Mymensingh. Previously, Mir et al. [75] showed that 100\% Salmonella were resistant to penicillin and oxacillin, and Sharma et al. [76] found 95.71\% ampicillin-resistant Salmonella from poultry samples in India.

Several genes are known to be linked with resistance against penicillin. A study in Bangladesh has recently confirmed the presence of the $\beta$-lactam-resistant $b l a_{\mathrm{TEM}}$ gene in $73.30 \%, 63.60 \%$ and $50 \%$ of $S$. Typhimurium isolates from broilers, sonali and indigenous chickens, respectively [47]. Parvin et al. [43] also detected the bla $a_{\mathrm{TEM}-1 \text {-resistant }}$ gene of Salmonella from chicken in Bangladesh. Previously, Alam et al. [38] detected the bla $a_{\text {TEM-1 }}(82.85 \%)$ gene in Salmonella from broiler samples in Bangladesh. Likely, in Egypt, Sabry et al. [77] reported the $\beta$-lactam-resistant $b l a_{\text {TEM }}$ gene from healthy and diseased chickens. Earlier, Wajid et al. [78] detected the bla $a_{\text {TEM-1 }}$ (72.70\%) gene in Salmonella from the layers in Pakistan. In addition, Giuriatti et al. [79] detected the bla TEM-1 (83.33\%) gene from chickens in Brazil. Similarly, the bla ${ }_{\mathrm{TEM}-1}$-resistant gene of Salmonella from poultry was detected in Brazil and China by Souza et al. [80] and Wang et al. [81], respectively. Therefore, the exhibition of higher resistance patterns of Salmonella to penicillin group of antimicrobials in poultry may well relate to the longtime use of these antimicrobials.

\subsection{Resistance to Cephalosporins}

Cephalosporins are a class of $\beta$-lactam antimicrobials [82] that might be broadly utilized as crucial drugs to treat important bacterial diseases in people and animals [83]. For a long time, there seems to be an increment in records of resistance in Salmonella to cephalosporin in people and food producing animals universally. In Bangladesh, cephalosporins are also used in poultry.

Cephalexin, a class of first-generation cephalosporins, was found to be not utterly effective against Salmonella. For example, in Dhaka city, Salmonella isolated from egg surface, hand wash, cloacal swab, intestinal fluid and soil samples were found about $50 \%$ to $65 \%$ resistant to cephalexin [23,24]. Similarly, Akond et al. [24] in Dhaka and Chaudhary et al. [37] in Chittagong observed $50.00 \%$ to $96.44 \%$ resistance of Salmonella to ceftriaxone and cefixime since they are used as the third generation of cephalosporins. Dutil et al. [84] and Jeon et al. [85] recorded ceftiofur-resistant Salmonella from poultry meat in Canada and Korea, respectively. The use of ceftiofur (a third-generation cephalosporin) in farm animals has severe public health concerns since it leads to resistance to extended-spectrum cephalosporins such as ceftriaxone and cephamycins [86]. These findings point to the need for a better monitoring scheme and guidelines for the prudent use of antimicrobial medicines in Bangladesh's poultry sector.

\subsection{Resistance to Carbapenems}

Ertapenem, imipenem and meropenem belong to carbapenem group of antimicrobials. Imipenem features a wide range of action against aerobic and anaerobic microbes. Parvin et al. [43] reported $48.60 \%$ resistance to imipenem in Salmonella isolates from chicken frozen meat. Tawyabur et al. [42] also observed $40.74 \%$ resistance of meropenem in healthy and diseased turkeys. These findings demonstrate that we must be concerned since antibiotics from carbapenem group are frequently used as "last-line agents" to cure diseases caused by MDR Gram-negative bacteria [87-89]. Earlier, Wajid et al. [78] also reported resistance of S. Typhimurium for imipenem $(79.40 \%)$, doripenem $(61.70 \%)$, and meropenem $(54.50 \%)$ in poultry in Pakistan. Carbapenems are generally considered to be last-line antimicrobials to treat hospitalized patients affected by different bacterial infections. However, it has been unclear how this sort of resistance has entered the poultry, as these sorts of antimicrobials are not allowed for use in the poultry industry. Higher rates of carbapenem resistance are in poultry is very much alarming, so it is important to ensure quality control and confirmation measures for the poultry processing and production industry. 


\subsection{Resistance to Fluroquinolones}

Fluoroquinolones are a group of antimicrobials that are used universally. Ciprofloxacin, a sort of fluoroquinolone antimicrobials, is commonly used to treat a vast extend infections of humans, poultry, and other animals. As a result, Salmonella isolated from broilers, layers and turkeys showed periodical increase in resistance to ciprofloxacin, ranging from $20 \%$ to $100 \%[24,28,30,37,42,44,47]$ in different districts of Bangladesh in between 2012 to 2021 . The scenario is similar in neighboring countries. Hassan et al. [27] revealed $87.50 \%$ resistance of Salmonella to pefloxacin inlayer chickens, whereas Parvin et al. [43] reported 70.30\% resistance in the broilers. Sharma et al. [76] observed $82.86 \%$ resistance of Salmonella to ciprofloxacin in chickens in India. Similarly, in Pakistan, $92.60 \%$ of $S$. Typhimurium and $100 \%$ of $S$. Enteritidis were resistant to pefloxacin in poultry birds [78]. Furthermore, $60 \%$ of $S$. Typhimurium and $65.85 \% \mathrm{~S}$. Enteritidis showed resistance in layers in Chittagong, Gazipur, Narsingdi, Tangail, and Brahmanbaria [30,44]. Nalidixic acid (NA) is the first of the synthetic quinolone antibiotics. Various degrees of resistance found against NA have been reported in Salmonella in Bangladesh. About 20\% to 100\% resistance found in Salmonella to NA secluded from poultry and environmental samples at a different region of Bangladesh [23-25,32,40,43,45,47]. Early, Nikolić et al. [90] observed 95.50\% resistance of Salmonella to NA in broiler isolates in Serbia. These discoveries highlight the requirement for the execution of reconnaissance frameworks that center on nourishment cleanliness, utilize antimicrobials in poultry farming and continuously check the quality of retail meat items.

\subsection{Resistance to Aminoglycosides}

Aminoglycosides are antimicrobials that repress bacterial protein synthesis [91]. Streptomycin is one of the primary aminoglycoside antibiotics presented in human medication. It is additionally utilized in animals and poultry. Salmonella resistance to streptomycin has been documented in chicken in Bangladesh, ranging from 38\% to $100 \%[25,29,35,38,47]$. Similarly, Souza et al. [80] reported $98.30 \%$ resistance in Salmonella to streptomycin from poultry in Brazil. Gentamicin, a broad-spectrum aminoglycoside antibiotic, has long been used to treat Gram-negative and Gram-positive microbes in poultry in Bangladesh. Extremely recently, Siddiky et al. [47] reported $86.70 \%$ resistance in Salmonella to gentamicin in the broilers, sonali, and indigenous chickens in Bangladesh. Previously, Wajid et al. [78] observed $64.70 \%$ resistance to gentamicin from $S$. Typhimurium isolates in poultry in Pakistan. Earlier, Hassan et al. [27] and Paul et al. [32] also observed significant amount of resistance to other aminoglycosides in Salmonella such as kanamycin in the layers. Alam et al. [38] reported the aminoglycoside-resistant gene aadA1 (77.10\%) in Salmonella isolates from cloacal swabs and a litter of broilers in Mymensingh. Siddiky et al. [47] observed the $s t r A / B$ $(33.33 \%)$ resistance gene in $S$. Typhimurium isolates from broilers ceca at wet markets in Dhaka. Earlier, Wajid et al. [78] reported aminoglycosides aad $A 1(35.20 \%), \operatorname{str} A(20.50 \%)$ and strB $(41.10 \%)$ resistance genes, respectively, in $S$. Typhimurium from poultry in Pakistan.

\subsection{Resistance to Macrolides}

Macrolides are bacteriostatic, which means that instead of killing bacteria, they limit or restrain their growth [92]. Azithromycin is an azalide, a sort of macrolide antibiotic. Salmonella in Bangladeshi poultry has been found to have varying degrees of azithromycin resistance, ranging from $18.18 \%$ to $81.25 \%$ [25,26,33-35,39,40,48]. Last year, Tîrziu et al. [93] also reported $88.20 \%$ resistance in Salmonella to azithromycin was isolated from store raw poultry in Romania. Erythromycin is generally used to cure many diseases of chicken in Bangladesh. About $62.50 \%$ to $100.00 \%$ resistance found in Salmonella to erythromycin in layer samples [23,24,30,32], while $64.28 \%$ to $100.00 \%$ resistance observed [25,28,29,33-35,39] in case of broiler samples. Cardoso I et al. [94] in Brazil and Sharma et al. [76] in India also reported $100 \%$ resistance of avian Salmonella to erythromycin. These higher resistances of Salmonella to macrolides are not unprecedented since in numerous cases, many individuals of Enterobacteriaceae are found resistant to these compounds. 


\subsection{Resistance to Lincosamides}

Clindamycin is an antibiotic that is used to treat a variety of bacterial infections. It belongs to the lincosamides family and operates by preventing bacteria from producing protein [95]. Sultana et al. [26] reported 84\% resistance in Salmonella to clindamycin in poultry in Bangladesh. Similarly, Yildirim et al. [96] in Turkey and Mir et al. [75] in India detected $97 \%$ and $100 \%$ resistance in Salmonella isolated from poultry as resistance to clindamycin, respectively. So, it is obligatory to actualize strict control over the man handle of antimicrobials, especially in the poultry segment. Appropriate logical and open wellbeing controls are required to scrutinize the non-judicial utilization of antimicrobials.

\subsection{Resistance to Tetracyclines}

One of the heavily used antibiotics in veterinary medication is tetracycline. A variable level of tetracycline resistance has been noticed in Salmonella to tetracycline in poultry in Bangladesh. Several studies had reported about $65 \%$ to $100 \%$ resistance in Salmonella to tetracycline and oxytetracycline in layers and broilers in Bangladesh [25,27,29,30,32-34,38-40,42,43,46,47]. Recently, Alam et al. [38] and Tawyabur et al. [42] detected tetracycline-resistant phenotype and the tetracycline-resistant gene tet $A$ in Salmonella in poultry in Bangladesh. More specifically, extremely recently, Siddiky et al. [47] identified tetracycline tet Agene $80 \%, 90.90 \%$ and $100 \%$ $S$. Typhimurium isolates of broilers, sonali, and indigenous chickens' ceca, respectively, in Bangladesh. Earlier, Sharma et al. [76] observed 100\% resistance to tetracycline and also detected the tet $A$-resistant gene in Salmonella in India.

Doxycycline is a broad-spectrum tetracycline class of antibiotic that is commonly used to treat different infections in humans and animals. A significant number of isolates resistant to doxycycline $(50.00 \%$ to $79.31 \%)$ has also been reported in Salmonella in poultry in Bangladesh [23,26,34,48]. Formerly, Waghamare et al. [97] also observed 100\% resistance in Salmonella to doxycycline in India. Higher rate of detection for the tetracycline-resistant gene in Salmonella from poultry environment is threat for both animals and humans. The ability of resistance potential of Salmonella to access the food web could expose individuals to life-threatening health risks. To reduce the rise of bacterial resistance in chicken farms in Bangladesh and around the globe, AMR reconnaissance protocols should be implemented.

\subsection{Resistance to Phenicols}

Chloramphenicol is a broad-spectrum antibiotic not currently used since it is a banned item due to its side effect on the host. However, it has long been used to treat numeric types of bacterial maladies in both individuals and animals [98]. Studies carried out throughout 2012 to 2021 have reported variable degree (20\% to 58\%) resistance in Salmonella to chloramphenicol in layer birds in Bangladesh [23,32,36,41,47]. In broilers, about $94.28 \%$ to $100 \%$ resistance was reported in Salmonella to chloramphenicol [25,38]. Alamet al. [38] also detected chloramphenicol resistance floR (94.28\%) gene from Salmonella isolates of broilers in Bangladesh. Previously, El-Sharkawy et al. [99] reported 100\% resistance to chloramphenicol in $S$. Typhimurium isolated from chicken in Egypt. These authors also detected the chloramphenicol-resistant gene floR $(79.30 \%)$ from these isolates [99]. The detection of the chloramphenicol-resistant floR gene of Salmonella in broiler carrying intl1 is of severe general well-being issues because their Salmonella zoonotic type and conceivable outcomes to access into the food web.

\subsection{Resistance to Rifampicin}

Rifampicin is used for the treatment of a few sorts of bacterial diseases, counting tuberculosis, Mycobacterium avium complex disease, and Legionnaires' disease [100]. In livestock and poultry, it has been used to some extent experimentally. However, reports are available showing resistance in Salmonella to rifampicin. Akond et al. [24] reported $60 \%$ resistance in Salmonella to rifampicin isolated from the egg surface, cloacal swabs, intestinal fluid, soil and hand washing samples of the layers. Later, Sultana et al. [26] also observed 88\% resistance in Salmonella to rifampicin isolated from the layers in Bangladesh. 
Previously Zdragas et al. [101] reported 33.30\% rifampicin resistance in avian Salmonella in Greece and Ramatla et al. [102] reported 100\% rifampicin resistance in avian Salmonella in South Africa. Horizontal transfer of rifampicin-resistant genes from human isolates to avian species might be linked with this observed resistance in avian isolates.

\subsection{Resistance to Glycopeptides}

Vancomycin is a glycopeptide antimicrobial useful to treat skin diseases, circulatory system diseases, endocarditis, bone and joint diseases, and meningitis in humans [103]. Although it is not used in poultry, Sultana et al. [26] reported 78\% resistance in Salmonella to vancomycin in the layers in Savar. In India, Singh et al. [104] recorded 100\% resistance in avian Salmonella to vancomycin. Vancomycin works against the Gram-positive cell wall, so it was not unexpected to see resistance in Salmonella to vancomycin.

\subsection{Resistance to Sulpher Drugs}

Sulfonamides such as sulfamethoxazole are a widely used group of antimicrobials in poultry [105]. In Bangladesh, variable degrees of sulfamethoxazole resistance in Salmonella in the layers were recorded [32,45,48]. Rahman et al. [34] detected $75.86 \%$ resistance to sulfamethoxazole and Parvin et al. [43] also reported $89.20 \%$ resistance in Salmonella to sulfamethoxazole in the broilers. In Bangladesh, the percentages of resistance to sulfur medicines detected are close to those reported in other studies in Malaysia, which was $67.50 \%$ [106], and Ethiopia [107] where resistance was $60 \%$. Extremely recently, Siddiky et al. [47] detected sulfonamide resistance sul1 gene in $36.40 \%, 66.70 \%$ and $80 \%$ $S$. Typhimurium isolated from broiler, sonali and indigenous hens' ceca in Bangladesh, respectively. This gene has also been identified in Salmonella in India [108]. The evolution of sulfamethoxazole resistance in hens could be caused by irrational antimicrobial use in the production process or environmental drip. As a result, we should be concerned about developing and implementing an efficient national AMR surveillance strategy in order to assure food safety and market control.

\subsection{Resistance to Polymyxins}

Colistin is an antibiotic in the reserve group that is used as a last option for curing various MDR bacterial diseases in humans. Despite the fact that there are limits to the utilization of colistin in domesticated fowls in Bangladesh, it has long been used to treat Gram-negative bacterial diseases in this country. A significant level of colistin resistance was observed as ranging from $50 \%$ to $92.68 \%$ in Salmonella in broilers and layers in Bangladesh [27,28,30,41,44]. Similarly, Phiri et al. [109] also reported 78.70\% colistin resistance in Salmonella in Zambia. The main reservoirs for colistin resistance and transmission have been identified as livestock and poultry [110]. Detection of colistin resistance is extremely concerning for public health. In Bangladesh, Uddin et al. [44] detected colistin resistance mcr1 gene in Salmonella in poultry. Earlier, Quesada et al. [111] and Moreno et al. [112] also identified colistin resistancemcr1 gene in poultry in Spain and Brazil, respectively. Globally, increased resistance to colistin is quickly growing, posing a hazard to human health. Colistin-resistant genes are found in the plasmid. There are conceivable outcomes for exchanging these resistance genes from resistant to other sensitive isolates, making the situation more aggravated.

Overall antimicrobial-resistant profile of poultry Salmonella in Bangladesh as reported in the literature on a yearly basis is presented in Figure 4. 


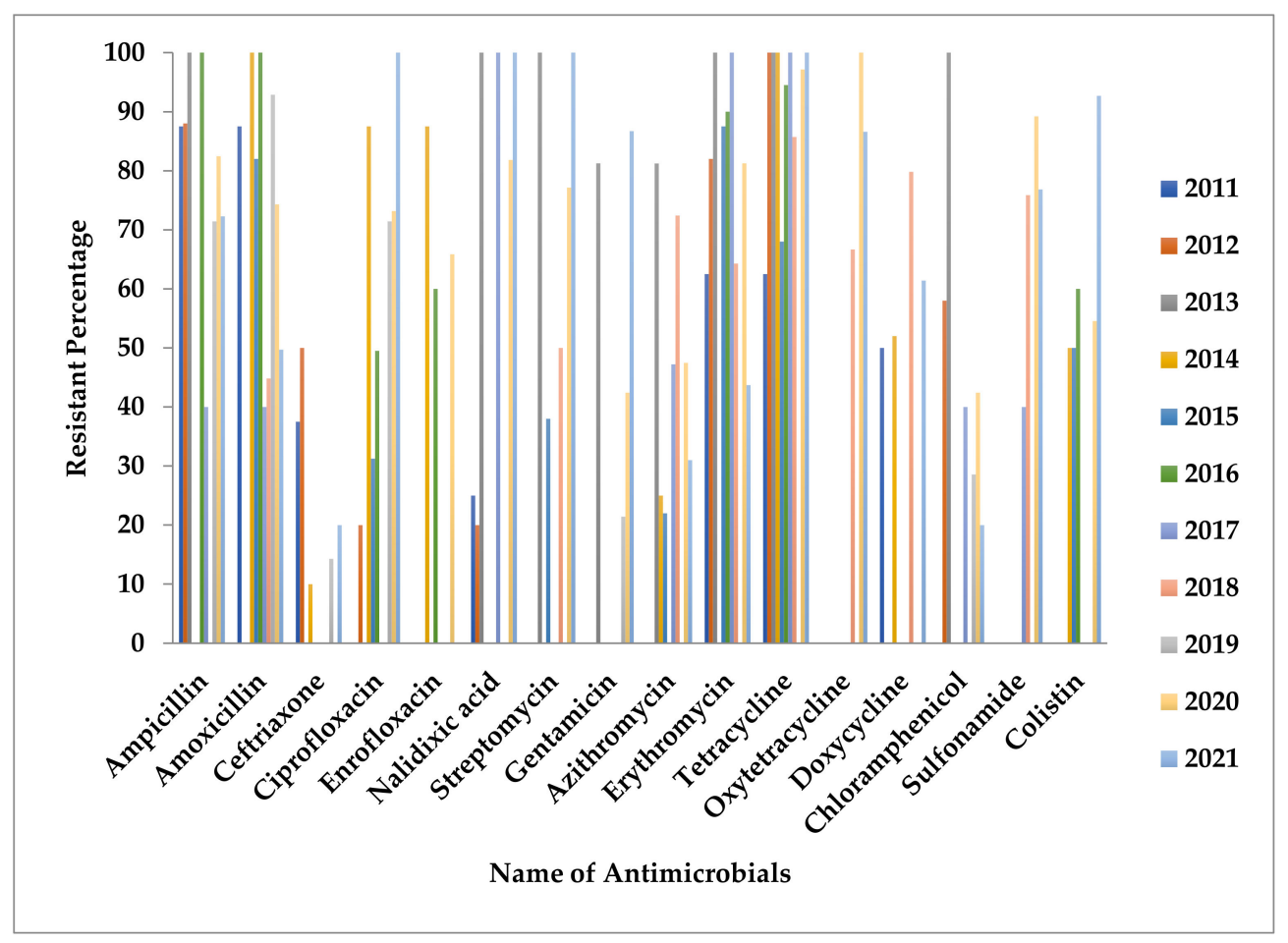

Figure 4. Presents antimicrobial-resistant profiles of Salmonella based on year of publications.

\section{Public Health Significance of Salmonella}

Salmonella is a major issue for the public health in many flourishing nations due to the lack of safe drinking water, inadequate hygiene facility and incorrect antimicrobial drug uses. Salmonella infection affects nearly 30 million individuals worldwide every year, whereas the scenario in Bangladesh is estimated to be between 292-395 cases per 100,000 persons each year [113-115]. Foodborne zoonoses, such as salmonellas, pose a dangerous threat to the food industry and food safety around the world. All necessary measures must be taken to overcome them in this way, as it entails improving public health and assembling food supply needs. Salmonella anticipation can be achieved over time using a holistic methodology that is comprehensive and all-encompassing. Salmonellosis has a substantial social and financial impact as a result of financial costs to the poultry industry, particularly to infected people and their families [116]. Human infection with Salmonella that is MDR in nature could be highly expensive to treat due to the cost of effective alternative medicines and longtime patient care in hospitals unless covered by health insurance [117].

\section{Economic Impact of Salmonellosis}

Salmonella is responsible for great economic impact all over the world. It usually spreads from animal to human and affects the poultry business globally. It also causes economic loss in the poultry sector in Bangladesh; however, the exact data on such economic loss are not well documented. Economic losses are due to high treatment and other management costs, loss of production and mortality. Only some countries submit reports on the financial impact of Salmonella, and data on the cost of foodborne illness in underdeveloped countries are often unavailable [118]. Foodborne infections have a significant impact nearly one out of every ten people becomes ill each year and responsible for loss of 33 million lives per year. According to the Centers for Disease Control and Prevention (CDC), Salmonella causes 1.2 million infections, 23,000 hospitalizations, and 450 deaths in the United States every year [119]. Food is responsible for approximately 1 million of these illnesses. 
The cost of disease is determined by its frequency, severity and influence on one's health. Estimates of the cost of foodborne diseases are critical in driving federal attempts to stop foodborne diseases in the United States. The first cost estimates for sixteen foodborne illnesses were issued by the USDA's Economic Research Service (ERS) in 1989 [120]. In 2000, the ERS estimated that sickness caused by five important foodborne pathogens, including Salmonella, cost nearly USD 7 billion per year.

For the first time in a decade, new full cost of illness estimates was released in 2012. Scharff [121] employed an upgraded tariff of illness design that included a metric for agony, distress, and functional incapacity that is more inclusive. According to Scharff [121], the annual cost of foodborne diseases for all pathogenic organisms could be as high as USD 77.7 billion. In that year, Hoffman et al. [122] calculated that disease caused by fourteen main pathogenic organisms costs USD 14.1 billion in the United States.

The cost per pathogen rankings in the two studies is nearly identical. According to Scharff [121] and Hoffmann et al. [122], the expense of non-typhoidal Salmonella is the greatest of all foodborne infections. The entire financial cost of foodborne Salmonella in the United States in 2013 was USD 3.7 billion [123]. The annual cost of foodborne Salmonella is USD 1.14 billion [121]. According to David Byrne, EU Commissioner for Health and Consumer Protection, the cost of foodborne Salmonella alone in EU countries is expected to be up to EUR 2.8 billion per year (EU Commission, 2003) [124]. The yearly cost of foodborne salmonellosis in Denmark was estimated to be USD 15.5 million in 2001 and it is roughly $0.009 \%$ of its national GDP. A Salmonella management system has already been in operation in the country for some years, with an estimated annual cost of around USD 14.1 million [118]. In the Netherlands, the yearly financial costs of human salmonellae were estimated to be EUR 32-90 million [125].

\section{Salmonellosis Prevention and Control}

Salmonellosis is a serious concern in the food industry. Since January 2006, the European Union has established standards that include yields, biosecurity indicators, and the ban of the use of antibacterial agents as development promoters across the poultry value chain [126]. Meat and process items of chickens are regularly connected with episodes of salmonellosis therefore significant spread of illness occurred [127]. Salmonella avoidance and control can be accomplished by receiving the standards of HACCP [128].

For the poultry farm's general management, hygiene and biosecurity should be required [129]. These means are vital in contamination control. Approaching poultry should be in good health and purchased from reputable sources with assured quality. Moreover, Salmonella can be introduced in chicken homesteads by transportation, laborers, apparel, gumboots, gear, water, foods, trash, creepy crawlies, rodents, wild birds, pets, hardware and numerous components. It should be able to prevent Salmonella from entering the farm by regulating who enters the property, wearing protective clothing, and wearing cleaned footwear. Laborers should also be aware of important sterile standards, such as keeping hands and feet clean. Cleaning and sterilizing should be done on a regular basis while organizing the administration of the entire homestead. Chicken farms should be sterilized using examples such as floors, dividers, drinking water, dining areas and the temperature. It is believed that if an antimicrobial usage approach is implemented, public knowledge of antimicrobial hazards will rise [130,131]. The cooperation between human health, sanitation, livestock health, One Health access and pollution methodologies along with animals, markets, caterings, and purchasers to limit tainting and decrease spread of Salmonella is essential to reduce the threat of foodborne pathogens. Furthermore, constant observing of the degree of Salmonella obstruction worldwide is vital for physicians to help useful treatment alternatives for salmonellosis, particularly for sick persons accepting antimicrobial treatment [132,133]. 


\section{Current Status and Future Research}

Salmonellosis is one of the most common zoonotic diseases in Bangladesh. Every year millions of people, animals, and poultry are affected by Salmonella infection. Salmonellosis is frequently associated with high mortality rates that are closely $90 \%$, resulting in significant economic losses [134]. According to the European Food Safety Authority (EFSA), the overall economic cost of human salmonellosis could be as high as EUR 3 billion per year [135].

In addition, to overcome bacterial AMR, phage therapy could be an alternative way [136]. These phages, also known as bacteriophages, are actually viruses having ability to infect bacterial cells and kill them by lysis. Experimental study in mice showed phages as effective against Salmonella [137].

According to the last decade survey in Bangladesh, epidemiological, AMR and few levels of genetic exploration were observed in avian salmonellosis. We need more studies on why Salmonella becomes resistant frequently in poultry production, and the foodborne illness is more substantial in Bangladesh. In addition, food hygiene and food safety practices and biosecurity in the poultry production units in Bangladesh are not well standard in many cases, which needs to be properly addressed. Good hygiene and manufacturing practices in the food production units and strict biosecurity is a must to overcome zoonoses and control of Salmonellosis in the poultry production units.

\section{Conclusions}

Salmonellae are major foodborne pathogenic bacterial organisms. Chicken and processed items are a potential origin for antimicrobial resistance to Salmonella. The farm environment could also be a major source and reservoir for MDR Salmonella. Treatment of MDR bacteria is complicated, expensive, and often required long-time attention and monitoring. Salmonella resistance has already been documented in poultry in Bangladesh. Antimicrobials only have to be applied after conducting the sensitivity test. Law enforcement by the concerned government agencies should be implemented to restrict easy access and use of antimicrobials. It also needs to be ensured that general people are aware of the fatal consequences of AMR through various awareness building programs.

Author Contributions: Conceptualization, M.T.R., Y.A., A.N. and M.J.H.; literature collection and curation, M.J.H., M.T.R., F.M.B., Y.A., A.N. and A.R.; writing original draft, M.J.H., F.M.B., M.A.S., M.S.I. (Md. Saiful Islam), M.A.I. and S.I.; writing—review and editing, M.T.R., Y.A., A.N., J.H., M.S.I. (Md. Shafiqul Islam) and A.R.; final proofreading, M.T.R., Y.A. and A.N. All authors have read and agreed to the published version of the manuscript.

Funding: This research was funded by Bangladesh Agricultural University Research System (BAURES; 2019/8/BAU) and University Grants Commission (2020/28/UGC) of Bangladesh.

Institutional Review Board Statement: Not applicable.

Informed Consent Statement: Not applicable.

Data Availability Statement: Not applicable.

Acknowledgments: We are grateful to Khalada Zesmin, ULO, Kishoreganj, Bangladesh for her valuable comments and suggestions.

Conflicts of Interest: The authors declare no conflict of interest.

\section{References}

1. Ievy, S.; Islam, M.S.; Sobur, M.A.; Talukder, M.; Rahman, M.B.; Khan, M.F.R.; Rahman, M.T. Molecular Detection of Avian Pathogenic Escherichia coli (APEC) for the First Time in Layer Farms in Bangladesh and Their Antibiotic Resistance Patterns. Microorganisms 2020, 8, 1021. [CrossRef]

2. Livestock Economy. Livestock Economy at a Glance 2019-2020. Department of Livestock Services. Available online: http: //www.dls.gov.bd/site/page/22b1143b-9323-44f8-bfd8-647087828c9b/Livestock-Economy (accessed on 14 July 2021).

3. Islam, M.S.; Sabuj, A.A.; Haque, Z.F.; Pondit, A.; Hossain, M.G.; Saha, S. Seroprevalence and risk factors of avian reovirus in backyard chickens in different areas of Mymensingh district in Bangladesh. J. Adv. Vet. Anim. Res. 2020, 7, 546-553. [CrossRef] 
4. Hamid, M.A.; Rahman, M.A.; Ahmed, S.; Hossain, K.M. Status of poultry industry in Bangladesh and the role of private sector for its development. Asian J. Poult. Sci. 2017, 11, 1-3. [CrossRef]

5. Sabuj, A.A.; Mahmud, T.; Barua, N.; Rahman, M.A.; Islam, M.S.; Bary, M.A. Passive surveillance of clinical poultry diseases in an Upazila Government Veterinary Hospital of Bangladesh. Afr. J. Microbiol. Res. 2019, 13, 632-639. [CrossRef]

6. Islam, M.S.; Paul, A.; Talukder, M.; Ray, K.; Sobur, M.A.; Ievy, S.; Nayeem, M.M.H.; Rahman, S.; Nazir, K.N.; Hossain, M.T.; et al. Migratory birds travelling to Bangladesh are potential carriers of multi-drug resistant Enterococcus spp., Salmonella spp., and Vibrio spp. Saudi J. Biol. Sci. 2021, 28, 5963-5970. [CrossRef]

7. Attia, Y.A.; Ellakany, H.F.; El-Hamid, A.A.; Bovera, F.; Ghazaly, S. Control of Salmonella enteritidis infection in male layer chickens by acetic acid and/or prebiotics, probiotics and antibiotics. Arch. Geflügelk. 2012, 76, 239-245.

8. Pal, M.; Merera, O.; Abera, F.; Rahman, M.T.; Hazarika, R.A. Salmonellosis: A major foodborne disease of global significance. Beverage Food World. 2015, 12, 21-24.

9. Gast, R.K. Detecting infections of chickens with recent Salmonella pullorum isolates using standard serological methods. Poult. Sci. 1997, 76, 17-23. [CrossRef]

10. El-Ghany, W.A.A. Salmonellosis: A food borne zoonotic and public health disease in Egypt. J. Infect. Dev. Ctries. 2020, 14, 674-678. [CrossRef] [PubMed]

11. Rahman, M.T.; Sobur, M.A.; Islam, M.S.; Ievy, S.; Hossain, M.J.; El Zowalaty, M.E.; Rahman, A.T.; Ashour, H.M. Zoonotic Diseases: Etiology, Impact, and Control. Microorganisms 2020, 8, 1405. [CrossRef] [PubMed]

12. Islam, M.S.; Sobur, M.A.; Rahman, S.; Ballah, F.M.; Ievy, S.; Siddique, M.P.; Rahman, M.; Kafi, M.A.; Rahman, M.T. Detection of blaTEM, blaCTX-M, blaCMY, and blaSHV Genes Among Extended-Spectrum Beta-Lactamase-Producing Escherichia coli Isolated from Migratory Birds Travelling to Bangladesh. Microb. Ecol. 2021, in press. [CrossRef]

13. Islam, M.S.; Nayeem, M.M.H.; Sobur, M.A.; Ievy, S.; Islam, M.A.; Rahman, S.; Kafi, M.A.; Ashour, H.M.; Rahman, M.T. Virulence Determinants and Multidrug Resistance of Escherichia coli Isolated from Migratory Birds. Antibiotics 2021, 10, 190. [CrossRef]

14. Urmi, M.R.; Ansari, W.K.; Islam, M.S.; Sobur, M.A.; Rahman, M.; Rahman, M.T. Antibiotic resistance patterns of Staphylococcus spp. isolated from fast foods sold in different restaurants of Mymensingh, Bangladesh. J. Adv. Vet. Anim. Res. 2021, 8, $274-281$. [CrossRef]

15. Orubu, E.S.F.; Samad, M.A.; Rahman, M.T.; Zaman, M.H.; Wirtz, V.J. Mapping the Antimicrobial Supply Chain in Bangladesh: A Scoping-Review-Based Ecological Assessment Approach. Glob. Health Sci. Pract. 2021, in press. [CrossRef]

16. Orubu, E.S.; Zaman, M.H.; Rahman, M.T.; Wirtz, V.J. Veterinary antimicrobial resistance containment in Bangladesh: Evaluating the national action plan and scoping the evidence on implementation. J. Glob. Antimicrob. Resist. 2020, 21, 105-115. [CrossRef] [PubMed]

17. World Health Organization. Global Action Plan on Antimicrobial Resistance. 2015. Available online: https://apps.who.int/iris/ handle/10665/193736 (accessed on 14 July 2021).

18. World Health Organization. Bangladesh: Antimicrobial Resistance Containment in Bangladesh 2017-2022. Available online: https: //www.who.int/publications/m/item/bangladesh-antimicrobial-resistance-containment-in-bangladesh-2017-2022 (accessed on 14 July 2021).

19. Davies, J.; Davies, D. Origins and evolution of antibiotic resistance. Microbiol. Mol. Biol. Rev. 2020, 74, 417-433. [CrossRef] [PubMed]

20. Duong, V.T.; Tuyen, H.T.; Van Minh, P.; Campbell, J.I.; Phuc, H.L.; Nhu, T.D.; Tu, L.T.; Chau, T.T.; Nhi, L.T.; Hung, N.T.; et al. No clinical benefit of empirical antimicrobial therapy for pediatric diarrhea in a high-usage, high-resistance setting. Clin. Infect. Dis. 2018, 66, 504-511. [CrossRef] [PubMed]

21. Iwamoto, M.; Reynolds, J.; Karp, B.E.; Tate, H.; Fedorka-Cray, P.J.; Plumblee, J.R.; Hoekstra, R.M.; Whichard, J.M.; Mahon, B.E. Ceftriaxone-resistant nontyphoidal Salmonella from humans, retail meats, and food animals in the United States, $1996-2013$. Foodborne Pathog. Dis. 2017, 14, 74-83. [CrossRef] [PubMed]

22. Tyson, G.H.; Tate, H.P.; Zhao, S.; Li, C.; Dessai, U.; Simmons, M.; McDermott, P.F. Identification of plasmid-mediated quinolone resistance in Salmonella isolated from swine ceca and retail pork chops in the United States. Antimicrob. Agents Chemother. 2017, 61, e01318-17. [CrossRef]

23. Ahmed, M.M.; Rahman, M.M.; Mahbub, K.R. Characterization of antibiotic resistant Salmonella spp. isolated from chicken eggs of Dhaka city. J. Sci. Res. 2011, 3, 191-196. [CrossRef]

24. Akond, M.A.; Shirin, M.; Alam, S.; Hassan, S.M.; Rahman, M.M.; Hoq, M. Frequency of drug resistant Salmonella spp. isolated from poultry samples in Bangladesh. Stamford J. Microbiol. 2012, 2, 15-19. [CrossRef]

25. Jahan, F.; Kabir, S.L.; Amin, M.M. Identification and antimicrobial resistance profiles of Salmonellae isolated from the broiler dressing plants associated with their environments. Adv. Res. J. Microbiol. 2013, 1, 1-9.

26. Sultana, M.; Bilkis, R.; Diba, F.; Hossain, M.A. Predominance of multidrug resistant zoonotic Salmonella Enteritidis genotypes in poultry of Bangladesh. J. Poult. Sci. 2014, 51, 424-434. [CrossRef]

27. Hassan, M.M.; Amin, K.B.; Ahaduzzaman, M.; Alam, M.; Faruk, M.S.; Uddin, I. Antimicrobial resistance pattern against E. coli and Salmonella in layer poultry. Res. J. Vet. Pract. 2014, 2, 30-35. [CrossRef]

28. Aditya, A. Drug resistant Salmonella in broiler chicken sold at local market in Bangladesh and its public health significance. Afr. J. Biotechnol. 2015, 14, 2995-3000. [CrossRef] 
29. Al-Salauddin, A.S.; Hossain, M.F.; Dutta, A.; Mahmud, S.; Islam, M.S.; Saha, S.; Kabir, S.L. Isolation, identification, and antibiogram studies of Salmonella species and Escherichia coli from boiler meat in some selected areas of Bangladesh. Int. J. Basic Clin. Pharmacol. 2015, 4, 1000. [CrossRef]

30. Mahmud, T.; Hassan, M.M.; Alam, M.; Khan, M.M.; Bari, M.S.; Islam, A. Prevalence and multidrug-resistant pattern of Salmonella from the eggs and egg-storing trays of retail markets of Bangladesh. Int. J. One Health 2016, 2, 7-11. [CrossRef]

31. Parvej, M.S.; Nazir, K.N.; Rahman, M.B.; Jahan, M.; Khan, M.F.; Rahman, M. Prevalence and characterization of multi-drug resistant Salmonella enterica serovar Gallinarum biovar Pullorum and Gallinarum from chicken. Vet. World 2016, 9, 65. [CrossRef]

32. Paul, P.; Akther, S.; Ali, M.Z.; Banu, H.; Khan, M.S.; Khatun, M.M. Isolation, identification and antibiogram study of Salmonella spp. from poultry farm environment. Int. J. Anim. Biol. 2017, 3, 5-11.

33. Mamun, M.A.; Kabir, S.L.; Islam, M.M.; Lubna, M.; Islam, S.S.; Akhter, A.T.; Hossain, M.M. Molecular identification and characterization of Salmonella species isolated from poultry value chains of Gazipur and Tangail districts of Bangladesh. Afr. J. Microbiol. Res. 2017, 11, 474-481. [CrossRef]

34. Rahman, M.A.; Rahman, A.K.; Islam, M.A.; Alam, M.M. Detection of multi-drug resistant Salmonella from milk and meat in Bangladesh. Bangladesh J. Vet. Med. 2018, 16, 115-120. [CrossRef]

35. Islam, M.K.; Kabir, S.L.; Haque, A.Z.; Sarker, Y.A.; Sikder, M.H. Molecular detection and characterization of Escherichia coli, Salmonella spp. and Campylobacter spp. isolated from broiler meat in Jamalpur, Tangail, Netrokona and Kishoreganj districts of Bangladesh. Afr. J. Microbiol. Res. 2018, 12, 761-770. [CrossRef]

36. Hossain, M.S.; Hossain, K.M.; Sarker, M.M.; Hamid, S.A. Prevalence and antibiotic susceptibility of Salmonella from chicken eggs in Naogaon district of Bangladesh. J. Adv. Microbiol. 2019, 28, 1-6. [CrossRef]

37. Chaudhary, P.K.; Salam, S.A.; Reza, M.A.; Ahaduzzaman, M. High prevalence of ciprofloxacin and ceftriaxone resistance Salmonella in the retail chicken market of Chattogram, Bangladesh. Turk. J. Vet. Res. 2019, 3, 51-55.

38. Alam, S.B.; Mahmud, M.; Akter, R.; Hasan, M.; Sobur, A.; Nazir, K.N.H.; Noreddin, A.; Rahman, T.; El Zowalaty, M.E.; Rahman, M. Molecular Detection of Multidrug Resistant Salmonella Species Isolated from Broiler Farm in Bangladesh. Pathogens. 2020, 9 , 201. [CrossRef]

39. Mridha, D.; Uddin, M.N.; Alam, B.; Akhter, A.T.; Islam, S.S.; Islam, M.S.; Khan, M.S.; Kabir., S.L. Identification and characterization of Salmonella spp. from samples of broiler farms in selected districts of Bangladesh. Vet. World 2020, 13, 275. [CrossRef]

40. Karim, S.J.; Islam, M.; Sikder, T.; Rubaya, R.; Halder, J.; Alam, J. Multidrug-resistant Escherichia coli and Salmonella spp. isolated from pigeons. Vet. World 2020, 13, 2156. [CrossRef] [PubMed]

41. Hossain, M.J.; Islam, M.S.; Sobur, M.A.; Zaman, S.B.; Nahar, A.; Rahman, M.; Rahman, M.T. Exploring Poultry Farm Environment for Antibiotic Resistant Escherichia coli, Salmonella spp., and Staphylococcus spp. Having Public Health Significance. J. Bangladesh Agric. Univ. 2020, 18, 615-622. [CrossRef]

42. Tawyabur, M.; Islam, M.S.; Sobur, M.A.; Hossain, M.J.; Mahmud, M.M.; Paul, S.; Hossain, M.T.; Ashour, H.M.; Rahman, M.T. Isolation and Characterization of Multidrug-Resistant Escherichia coli and Salmonella spp. from Healthy and Diseased Turkeys. Antibiotics 2020, 9, 770. [CrossRef] [PubMed]

43. Parvin, M.S.; Hasan, M.M.; Ali, M.Y.; Chowdhury, E.H.; Rahman, M.T.; Islam, M.T. Prevalence and Multidrug Resistance Pattern of Salmonella Carrying Extended-Spectrum $\beta$-Lactamase in Frozen Chicken Meat in Bangladesh. J. Food Prot. 2020, 83, $2107-2121$. [CrossRef]

44. Uddin, M.B.; Hossain, S.M.B.; Hasan, M.; Alam, M.N.; Debnath, M.; Begum, R.; Roy, S.; Harun-Al-Rashid, A.; Chowdhury, M.S.R.; Rahman, M.M.; et al. Multidrug Antimicrobial Resistance and Molecular Detection of mcr-1 Gene in Salmonella Species Isolated from Chicken. Animals 2021, 11, 206. [CrossRef] [PubMed]

45. Sarker, B.R.; Ghosh, S.; Chowdhury, S.; Dutta, A.; Chandra Deb, L.; Krishna Sarker, B.; Sultana, T.; MozafforHossain, K.M. Prevalence and antimicrobial susceptibility profiles of non-typhoidal Salmonella isolated from chickens in Rajshahi, Bangladesh. Vet. Med. Sci. 2021, 7, 820-830. [CrossRef]

46. Talukder, M.; Islam, M.S.; Ievy, S.; Sobur, M.A.; Ballah, F.M.; Najibullah, M.; Rahman, M.B.; Rahman, M.T.; Khan, M.F.R. Detection of multidrug resistant Salmonella spp. from healthy and diseased broilers having potential public health significance. J. Adv. Biotechnol. Exp. Ther. 2021, 4, 248-255. [CrossRef]

47. Siddiky, N.A.; Sarker, M.S.; Khan, M.S.R.; Begum, R.; Kabir, M.E.; Karim, M.R.; Rahman, M.T.; Mahmud, A.; Samad, M.A. Virulence and Antimicrobial Resistance Profiles of Salmonella enterica Serovars Isolated from Chicken at Wet Markets in Dhaka, Bangladesh. Microorganisms 2021, 9, 952. [CrossRef] [PubMed]

48. Haque, A.K.M.Z.; Akter, M.R.; Islam, S.S.; Alam, J.; Neogi, S.B.; Yamasaki, S.; Kabir, S.M.L. Salmonella gallinarum in Small-Scale Commercial Layer Flocks: Occurrence, Molecular Diversity and Antibiogram. Vet. Sci. 2021, 8, 71. [CrossRef]

49. Dar, M.A.; Ahmad, S.M.; Bhat, S.A.; Ahmed, R.; Urwat, U.; Mumtaz, P.T.; Dar, T.A.; Shah, R.A.; Ganai, N.A. Salmonella typhimurium in poultry: A review. World's Poult. Sci. J. 2017, 73, 345-354. [CrossRef]

50. Judd, M.C.; Hoekstra, R.M.; Mahon, B.E.; Fields, P.I.; Wong, K.K. Epidemiologic patterns of human Salmonella serotype diversity in the USA, 1996-2016. Epidemiol. Infect. 2019, 147, e187. [CrossRef]

51. Barua, H.; Biswas, P.K.; Talukder, K.A.; Olsen, K.E.; Christensen, J.P. Poultry as a possible source of non-typhoidal Salmonella enterica serovars in humans in Bangladesh. Vet. Microbiol. 2014, 168, 372-380. [CrossRef] 
52. Siddiky, N.A.; Khan, M.S.R.; Sarker, M.S.; Bhuiyan, M.K.J.; Mahmud, A.; Rahman, M.T.; Ahmed, M.M.; Samad, M.A. Knowledge, attitude and practice of chicken vendors on food safety and foodborne pathogens at wet markets in Dhaka, Bangladesh. Food Control 2021, 131, 108456. [CrossRef]

53. Barua, H.; Biswas, P.K.; Olsen, K.E.; Christensen, J.P. Prevalence and characterization of motile Salmonella in commercial layer poultry farms in Bangladesh. PLoS ONE. 2012, 7, e35914. [CrossRef]

54. Islam, M.M.; Islam, M.N.; Sharifuzzaman, F.M.; Rahman, M.A.; Sharifuzzaman, J.U.; Sarker, E.H.; Shahiduzzaman, M.; Mostofa, M.; Sharifuzzaman, M.M. Isolation and identification of Escherichia coli and Salmonella from poultry litter and feed. Int. J. Nat. Soc. Sci. 2014, 1, 1-7.

55. Suresh, T.; Hatha, A.A.M.; Sreenivasan, D.; Sangeetha, N.; Lashmanaperumalsamy, P. Prevalence and antimicrobial resistance of Salmonella enteritidis and other salmonellas in the eggs and egg-storing trays from retails markets of Coimbatore, South India. Food Microbiol. 2006, 23, 294-299. [CrossRef]

56. Barbour, E.K.; Ayyash, D.B.; Alturkistni, W.; Alyahiby, A.; Yaghmoor, S.; Iyer, A.; Yousef, J.; Kumosani, T.; Harakeh, S. Impact of sporadic reporting of poultry Salmonella serovars from selected developing countries. J. Infect. Dev. Ctries. 2015, 9, 1-7. [CrossRef]

57. Wigley, P.; Hulme, S.D.; Powers, C.; Beal, R.K.; Berchieri, A., Jr.; Smith, A.; Barrow, P. Infection of the reproductive tract and eggs with Salmonella enterica serovar pullorum in the chicken is associated with suppression of cellular immunity at sexual maturity. Infect. Immun. 2005, 73, 2986-2990. [CrossRef]

58. Haider, G.; Chowdhury, E.H.; Hossain, M. Mode of vertical transmission of Salmonella enterica sub. enterica serovar Pullorum in chickens. Afr. J. Microbiol. Res. 2014, 8, 1344-1351. [CrossRef]

59. Jajere, S.M. A review of Salmonella enterica with particular focus on the pathogenicity and virulence factors, host specificity and antimicrobial resistance including multidrug resistance. Vet. World 2019, 12, 504. [CrossRef] [PubMed]

60. Wibisono, F.M.; Wibisono, F.J.; Effendi, M.H.; Plumeriastuti, H.; Hidayatullah, A.R.; Hartadi, E.B.; Sofiana, E.D. A review of salmonellosis on poultry farms: Public health importance. Syst. Rev. Pharm. 2020, 11, 481-486.

61. Dos Santos, A.M.P.; Ferrari, R.G.; Conte-Junior, C.A. Virulence factors in Salmonella typhimurium: The sagacity of a bacterium. Curr. Microbiol. 2019, 76, 762-773. [CrossRef] [PubMed]

62. Zamora-Sanabria, R.; Alvarado, A.M. Preharvest Salmonella risk contamination and the control strategies. Current Topics in Salmonella and Salmonellosis: InTechOpen 2017, 11, 193-213. [CrossRef]

63. Yanestria, S.M.; Rahmaniar, R.P.; Wibisono, F.J.; Effendi, M.H. Detection of invA gene of Salmonella from milkfish (Chanoschanos) at Sidoarjo wet fish market, Indonesia, using polymerase chain reaction technique. Vet. World 2019, 12, 170. [CrossRef]

64. Loharikar, A.; Vawter, S.; Warren, K.; Deasy III, M.; Moll, M.; Sandt, C.; Gilhousen, R.; Villamil, E.; Rhorer, A.; Briere, E.; et al. Outbreak of human Salmonella typhimurium infections linked to contact with baby poultry from a single agricultural feed store chain and mail-order hatchery, 2009. Pediatric Infect. Dis. J. 2013, 32, 8-12. [CrossRef]

65. Hedican, E.; Miller, B.; Ziemer, B.; LeMaster, P.; Jawahir, S.; Leano, F.; Smith, K. Salmonellosis outbreak due to chicken contact leading to a foodborne outbreak associated with infected delicatessen workers. Foodborne Pathog. Dis. 2010, 7, 995-997. [CrossRef]

66. Ricardo, A.; Soncini, M.V.D. Reducing Risks of Salmonella infections in Poultry. Poultry World. Available online: https: / / www.poultryworld.net/Special-Focus/Salmonella-special/Reducing-risks-of-Salmonella-infections-in-poultry / (accessed on 16 July 2021).

67. Zaheer, T. Salmonellosis: A Concise Review of One of Major Zoonotic Meat Borne Illness. Poultry Industry. 2018. Available online: https:/ / en.engormix.com/poultry-industry/articles/salmonellosis-concise-review-one-t41243.htm (accessed on 16 July 2021).

68. Salmonella as a Zoonosis. SVA Natl. Vet. Institute. 2020. Available online: https://www.sva.se/en/our-topics/feed-safety/ salmonella-as-a-zoonosis / (accessed on 16 July 2021).

69. Orpí, J.P. Importance of Salmonellosis as a Zoonosis. Veterinary Digital. 2020. Available online: https://www.veterinariadigital. $\mathrm{com} / \mathrm{en} /$ articulos /importance-of-salmonellosis-as-a-zoonosis / (accessed on 16 July 2021).

70. Hoque, M.; Mohiuddin, R.; Khan, M.; Hannan, M.; Alam, M. Outbreak of Salmonella in Poultry of Bangladesh and possible remedy. J. Adv. Biotechnol. Exp. 2019, 2, 87. [CrossRef]

71. Plym, L.F.; Wierup, M. Salmonella contamination: A significant challenge to the global marketing of animal food products. Rev. Sci. Tech. 2006, 25, 541-554. [CrossRef]

72. Lu, Y.; Wu, C.M.; Wu, G.J.; Zhao, H.Y.; He, T.; Cao, X.Y.; Dai, L.; Xia, L.N.; Qin, S.S.; Shen, J.Z. Prevalence of antimicrobial resistance among Salmonella isolates from chicken in China. Foodborne Pathog. Dis. 2019, 8, 45-53. [CrossRef]

73. Merchant, I.A.; Packer, R.A. Veterinary Bacteriology and Virology, 7th ed.; The Iowa University Press: Ames, IA, USA, 1969; pp. 286-306.

74. Kardos, N.; Demain, A.L. Penicillin: The medicine with the greatest impact on therapeutic outcomes. Appl. Microbiol. Biotechnol. 2011, 92, 677-687. [CrossRef]

75. Mir, I.A.; Kashyap, S.K.; Maherchandani, S. Isolation, serotype diversity and antibiogram of Salmonella enterica isolated from different species of poultry in India. Asian Pac. J. Trop. Biomed. 2015, 5, 561-567. [CrossRef]

76. Sharma, J.; Kumar, D.; Hussain, S.; Pathak, A.; Shukla, M.; Kumar, V.P.; Anisha, P.N.; Rautela, R.; Upadhyay, A.K.; Singh, S.P. Prevalence, antimicrobial resistance and virulence genes characterization of nontyphoidal Salmonella isolated from retail chicken meat shops in Northern India. Food Control 2019, 102, 104-111. [CrossRef] 
77. Sabry, M.A.; Abdel-Moein, K.A.; Abdel-Kader, F.; Hamza, E. Extended-spectrum $\beta$-lactamase-producing Salmonella serovars among healthy and diseased chickens and their public health implication. J. Glob. Antimicrob. Resist. 2020, 22, 742-748. [CrossRef]

78. Wajid, M.; Awan, A.B.; Saleemi, M.K.; Weinreich, J.; Schierack, P.; Sarwar, Y.; Ali, A. Multiple drug resistance and virulence profiling of Salmonella enterica serovars Typhimurium and Enteritidis from poultry farms of Faisalabad, Pakistan. Microb. Drug Resist. 2019, 25, 133-142. [CrossRef]

79. Giuriatti, J.; Stefani, L.M.; Brisola, M.C.; Crecencio, R.B.; Bitner, D.S.; Faria, G.A. Salmonella Heidelberg: Genetic profile of its antimicrobial resistance related to extended spectrum $\beta$-lactamases (ESBLs). Microb. Pathog. 2017, 109, 195-199. [CrossRef]

80. Souza, A.I.; Saraiva, M.M.; Casas, M.R.; Oliveira, G.M.; Cardozo, M.V.; Benevides, V.P.; Barbosa, F.O.; FreitasNeto, O.C.; Almeida, A.M.; Berchieri, A. High occurrence of $\beta$-lactamase-producing Salmonella Heidelberg from poultry origin. PLoS ONE 2020, 15, e0230676. [CrossRef]

81. Wang, W.; Peng, Z.; Baloch, Z.; Hu, Y.; Xu, J.; Zhang, W.; Fanning, S.; Li, F. Genomic characterization of an extensively-drug resistance Salmonella enterica serotype Indiana strain harboring blaNDM-1 gene isolated from a chicken carcass in China. Microbiol. Res. 2017, 204, 48-54. [CrossRef]

82. Loren, G.; Yamamoto, M.D. Case Based Pediatrics for Medical Students and Residents; Department of Pediatrics, University of Hawaii John, A. Burns School of Medicine: Honolulu, HI, USA, 2003.

83. Kim, J.S.; Yun, Y.S.; Kim, S.J.; Jeon, S.E.; Lee, D.Y.; Chung, G.T.; Yoo, C.K.; Kim, J. Rapid emergence and clonal dissemination of CTX-M-15-producing Salmonella enterica serotype Virchow, South Korea. Emerg. Infect. Dis. 2016, 22, 68. [CrossRef]

84. Dutil, L.; Irwin, R.; Finley, R.; Ng, L.K.; Avery, B.; Boerlin, P.; Bourgault, A.M.; Cole, L.; Daignault, D.; Desruisseau, A.; et al. Ceftiofur resistance in Salmonella enterica serovar Heidelberg from chicken meat and humans, Canada. Emerg. Infect. Dis. 2010, 16, 48. [CrossRef]

85. Jeon, H.Y.; Kim, Y.B.; Lim, S.K.; Lee, Y.J.; Seo, K.W. Characteristics of cephalosporin-resistant Salmonella isolates from poultry in Korea, 2010-2017. Poult. Sci. 2019, 98, 957-965. [CrossRef]

86. Dunne, E.F.; Fey, P.D.; Kludt, P.; Reporter, R.; Mostashari, F.; Shillam, P.; Wicklund, J.; Miller, C.; Holland, B.; Stamey, K.; et al. Emergence of domestically acquired ceftriaxone-resistant Salmonella infections associated with AmpC $\beta$-lactamase. JAMA 2000, 28, 3151-3156. [CrossRef]

87. Zhanel, G.G.; Wiebe, R.; Dilay, L.; Thomson, K.; Rubinstein, E.; Hoban, D.J.; Noreddin, A.M.; Karlowsky, J.A. Comparative review of the carbapenems. Drugs 2007, 67, 1027-1052. [CrossRef]

88. Nordmann, P.; Naas, T.; Poirel, L. Global spread of carbapenemase-producing Enterobacteriaceae. Emerg. Infect. Dis. 2011, 17, 1791. [CrossRef]

89. Patel, G.; Bonomo, R. "Stormy waters ahead": Global emergence of carbapenemases. Front. Microbiol. 2013, 4, 48. [CrossRef]

90. Nikolić, A.; Baltić, T.; Velebit, B.; Babić, M.; Milojević, L.; Đorđević, V. Antimicrobial resistance among Salmonella entericaserovarInfantis from broiler carcasses in Serbia. IOP Conf. Ser. Earth Environ. Sci. 2017, 85, 012077. [CrossRef]

91. Mingeot-Leclercq, M.P.; Glupczynski, Y.; Tulkens, P.M. Aminoglycosides: Activity and resistance. Antimicrob. Agents Chemother. 1999, 43, 727-737. [CrossRef]

92. Giguere, S.; Prescott, J.F.; Baggot, J.D.; Walker, R.D.; Dowling, P.M. Antimicrobial Therapy in Veterinary Medicine, 4th ed.; WileyBlackwell: Hoboken, NJ, USA, 2006; ISBN 978-0-8138-0656-3.

93. Tîrziu, E.; Bărbălan, G.; Morar, A.; Herman, V.; Cristina, R.T.; Imre, K. Occurrence and antimicrobial susceptibility profile of Salmonella spp. in raw and ready-to-eat foods and Campylobacter spp. in retail raw chicken meat in Transylvania, Romania. Foodborne Pathog. Dis. 2020, 17, 479-484. [CrossRef]

94. CardosoI, M.O.; RibeiroI, A.R.; Santos, L.R.; PilottoI, F.; Moraes, I.H.; Salle, I.C.T.P.; Rocha, I.L.S.; Nascimento, I.V.P. Resistência antimicrobiana em Salmonella Enteritidis isoladas de carcaças de frango. Braz. J. Microbiol. 2006, 37, 368-371.

95. "Clindamycin Hydrochloride". The American Society of Health-System Pharmacists. Archived from the Original on 5 September 2015. Retrieved 4 September 2015. Available online: https:/ / www.drugs.com/monograph/clindamycin-systemic.html (accessed on 17 July 2021).

96. Yildirim, Y.; Gonulalan, Z.; Pamuk, S.; Ertas, N. Incidence and antibiotic resistance of Salmonella spp. on raw chicken carcasses. Food Res. Int. 2011, 44, 725-728. [CrossRef]

97. Waghamare, R.N.; Paturkar, A.M.; Vaidya, V.M.; Zende, R.J.; Dubal, Z.N.; Dwivedi, A.; Gaikwad, R.V. Phenotypic and genotypic drug resistance profile of Salmonella serovars isolated from poultry farm and processing units located in and around Mumbai city, India. Vet. World 2018, 11, 682. [CrossRef]

98. "Chloramphenicol". The American Society of Health-System Pharmacists. Archived from the Original on 25 June 2015. Retrieved 1 August 2015. Available online: https:/ / www.drugs.com/monograph/chloramphenicol.html (accessed on 17 July 2021).

99. El-Sharkawy, H.; Tahoun, A.; El-Gohary, A.E.; El-Abasy, M.; El-Khayat, F.; Gillespie, T.; Kitade, Y.; Hafez, H.M.; Neubauer, H.; El-Adawy, H. Epidemiological, molecular characterization and antibiotic resistance of Salmonella enterica serovars isolated from chicken farms in Egypt. Gut Pathog. 2017, 9, 1-2. [CrossRef]

100. "Rifampin". The American Society of Health-System Pharmacists. Archived from the Original on 7 September 2015. Retrieved 1 August 2015. Available online: https:/ / www.drugs.com/monograph/rifampin.html (accessed on 17 July 2021).

101. Zdragas, A.; Mazaraki, K.; Vafeas, G.; Giantzi, V.; Papadopoulos, T.; Ekateriniadou, L. Prevalence, seasonal occurrence and antimicrobial resistance of Salmonella in poultry retail products in Greece. Lett. Appl. Microbiol. 2012, 55, 308-313. [CrossRef] 
102. Ramatla, T.; Taioe, M.O.; Thekisoe, O.M.; Syakalima, M. Confirmation of antimicrobial resistance by using resistance genes of isolated Salmonella spp. in chicken houses of north west, South Africa. World 2019, 9, 158-165. [CrossRef]

103. “Vancomycin". Drugs.com. 2 December 2019. Retrieved 24 December 2019. Available online: https://www.drugs.com/ international/vancomycin.html (accessed on 17 July 2021).

104. Singh, R.; Yadav, A.S.; Tripathi, V.; Singh, R.P. Antimicrobial resistance profile of Salmonella present in poultry and poultry environment in north India. Food Control 2013, 33, 545-548. [CrossRef]

105. "Co-trimoxazole". The American Society of Health-System Pharmacists. Archived from the Original on 6 September. Retrieved 1 August 2015. Available online: https:/ / www.drugs.com/monograph/co-trimoxazole.html (accessed on 17 July 2021).

106. Chuah, L.O.; Syuhada, A.K.S.; Suhaimi, I.M.; Hanim, T.F.; Rusul, G. Genetic relatedness, antimicrobial resistance and biofilm formation of Salmonella isolated from naturally contaminated poultry and their processing environment in northern Malaysia. Food Res. Int. 2018, 105, 743-751. [CrossRef]

107. Tibaijuka, B.; Molla, B.; Hildebrandt, G.; Kleer, J.; Salah, W. Antimicrobila resistance to Salmonellae isolated from retail raw chicken meat and giblets in Ethiopia. Bull. Anim. Health Prod. Afr. 2002, 50, 86-95. [CrossRef]

108. Adesiji, Y.O.; Deekshit, V.K.; Karunasagar, I. Antimicrobial-resistant genes associated with Salmonella spp. isolated from human, poultry, and seafood sources. Food Sci. Nutr. 2014, 2, 436-442. [CrossRef] [PubMed]

109. Phiri, N.; Mainda, G.; Mukuma, M.; Sinyangwe, N.N.; Banda, L.J.; Kwenda, G.; Muligisa-Muonga, E.; Flavien, B.N.; Mwansa, M.; Yamba, K.; et al. Antibiotic-resistant Salmonella species and Escherichia coli in broiler chickens from farms, abattoirs and open markets in selected districts of Zambia. J. Epidemiol. Res. 2020, 6, 1. [CrossRef]

110. Hoelzer, K.; Wong, N.; Thomas, J.; Talkington, K.; Jungman, E.; Coukell, A. Antimicrobial drug use in food-producing animals and associated human health risks: What, and how strong, is the evidence? BMC Vet. Res. 2017, 13, 1-38. [CrossRef]

111. Quesada, A.; Ugarte-Ruiz, M.; Iglesias, M.R.; Porrero, M.C.; Martínez, R.; Florez-Cuadrado, D.; Campos, M.J.; García, M.; Píriz, S.; Sáez, J.L.; et al. Detection of plasmid mediated colistin resistance (MCR-1) in Escherichia coli and Salmonella enterica isolated from poultry and swine in Spain. Res. Vet. Sci. 2016, 105, 134-135. [CrossRef]

112. Moreno, L.Z.; Gomes, V.T.; Moreira, J.; de Oliveira, C.H.; Peres, B.P.; Silva, A.P.S.; Thakur, S.; La Ragione, R.M.; Moreno, A.M. First report of $m c r-1$-harboring Salmonella enterica serovar Schwarzengrund isolated from poultry meat in Brazil. Diagn. Microbiol. Infect. Dis. 2019, 93, 376-379. [CrossRef]

113. Mogasale, V.; Maskery, B.; Ochiai, R.L.; Lee, J.S.; Mogasale, V.V.; Ramani, E.; Kim, Y.E.; Park, J.K.; Wierzba, T.F. Burden of typhoid fever in low-income and middle-income countries: A systematic, literature-based update with risk-factor adjustment. Lancet Glob. Health. 2014, 2, e570-e580. [CrossRef]

114. Stanaway, J.D.; Reiner, R.C.; Blacker, B.F.; Goldberg, E.M.; Khalil, I.A.; Troeger, C.E.; Andrews, J.R.; Bhutta, Z.A.; Crump, J.A.; Im, J.; et al. The global burden of typhoid and paratyphoid fevers: A systematic analysis for the Global Burden of Disease Study 2017. Lancet Infect. Dis. 2019, 19, 369-381. [CrossRef]

115. Theiss-Nyland, K.; Qadri, F.; Colin-Jones, R.; Zaman, K.; Khanam, F.; Liu, X.; Voysey, M.; Khan, A.; Hasan, N.; Ashher, F.; et al. Assessing the impact of a Vi-polysaccharide conjugate vaccine in preventing typhoid infection among Bangladeshi children: A protocol for a phase IIIb trial. Clin. Infect. Dis. 2019, 68, S74-S82. [CrossRef]

116. Sockett, P.N.; Roberts, J.A. The social and economic impact of salmonellosis: A report of a national survey in England and Wales of laboratory-confirmed Salmonella infections. Epidemiol. Infect. 1991, 107, 335-347. [CrossRef]

117. D'Aoust, J.Y. Salmonella and the international food trade. Int. J. Food Microbiol. 1994, 24, 11-31. [CrossRef]

118. WHO. WHO Media Centre. 2005. Available online: https:/ / www.who.int/ (accessed on 17 July 2021).

119. CDC. Salmonella. Centers for Disease Control and Prevention. 1600 Clifton Road Atlanta, GA 30329-4027 USA, 2018. Available online: https:/ / www.cdc.gov / nationalsurveillance/pdfs/2016-Salmonella-report-508.pdf (accessed on 17 July 2021).

120. USDA's Economic Research Service (ERS). 1989. Available online: https:/ /www.ers.usda.gov/data-products/ (accessed on 17 July 2021).

121. Scharff, R.L. Economic burden from health losses due to foodborne illness in the United States. J. Food Prot. 2012, 75, 123-131. [CrossRef]

122. Hoffmann, S.; Batz, M.B.; Morris, J.G. Annual cost of illness and quality-adjusted life year losses in the United States due to 14 foodborne pathogens. J. Food Prot. 2012, 75, 1292-1302. [CrossRef]

123. Scallan, E.; Mahon, B.E.; Hoekstra, R.M.; Griffin, P.M. Estimates of illnesses, hospitalizations and deaths caused by major bacterial enteric pathogens in young children in the United States. Pediatric Infect. Dis. J. 2013, 32, 217-221. [CrossRef]

124. Suksathit, S.; Tangwatcharin, P. Activity of organic acid salts in combination with lauric arginate against Listeria monocytogenes and Salmonella Rissen. Sci. Asia 2013, 39, 346-355. [CrossRef]

125. Van Duijkeren, E.W.J.B.; Wannet, W.J.B.; Houwers, D.J.; Van Pelt, W. Serotype and phage type distribution of Salmonella strains isolated from humans, cattle, pigs, and chickens in the Netherlands from 1984 to 2001. J. Clin. Microbiol. 2002, 40, $3980-3985$. [CrossRef]

126. Vandeplas, S.; Dauphin, R.D.; Beckers, Y.; Thonart, P.; Thewis, A. Salmonella in chicken: Current and developing strategies to reduce contamination at farm level. J. Food Prot. 2010, 73, 774-785. [CrossRef]

127. Saravanan, S.; Purushothaman, V.; Murthy, T.R.G.K.; Sukumar, K.; Srinivasan, P.; Gowthaman, V.; Balusamy, M.; Atterbury, R.; Kuchipudi, S.V. Molecular epidemiology of Nontyphoidal Salmonella in poultry and poultry products in India: Implications for human health. Indian J. Microbiol. 2015, 55, 319-326. [CrossRef] 
128. Media-OIE-World Organisation for Animal Health. Annual Report. 2019. Available online: https://www.report2019oie.fr/en/ (accessed on 18 July 2021).

129. Wibisono, F.J.; Sumiarto, B.; Untari, T.; Effendi, M.H.; Permatasari, D.A.; Witaningrum, A.M. CTX Gene of Extended Spectrum Beta-Lactamase (ESBL) Producing Escherichia coli on Broilers in Blitar, Indonesia. Syst. Rev. Pharm. 2020, 11, 396-403. [CrossRef]

130. Van Immerseel, F.; De Zutter, L.; Houf, K.; Pasmans, F.; Haesebrouck, F.; Ducatelle, R. Strategies to control Salmonella in the broiler production chain. World's Poult. Sci. J. 2009, 65, 367-392. [CrossRef]

131. Effendi, M.H.; Cicilia, R.; Rahmahani, J.; Tyasningsih, W. Public Awareness for Antimicrobial Resistance from Escherichia coli Isolated from Beef Sold on Several Wet Market in Surabaya, Indonesia. Indian J. Public Health Res. Dev. 2020, 11, 295-300. [CrossRef]

132. Antunes, P.; Mourão, J.; Campos, J.; Peixe, L. Salmonellosis: The role of poultry meat. Clin. Microbiol. Infect. 2016, 22, 110-121. [CrossRef]

133. Widodo, A.; Effendi, M.H.; Khairullah, A.R. Extended-spectrum beta-lactamase (ESBL)-producing Eschericia coli from livestock. Sys. Rev. Pharm. 2020, 11, 382-392.

134. Barrow, P.A.; Huggins, M.B.; Lovell, M.A.; Simpson, J.M. Observations on the pathogenesis of experimental Salmonella typhimurium infection in chickens. Res. Vet. Sci. 1987, 42, 194-199. [CrossRef]

135. Salmonella. European Food Safety Authority-EFSA. Available online: https://www.efsa.europa.eu/en/topics/topic/salmonella (accessed on 18 July 2021).

136. Brives, C.; Pourraz, J. Phage therapy as a potential solution in the fight against AMR: Obstacles and possible futures. Palgrave Commun. 2020, 6, 1-11. [CrossRef]

137. Nikkhahi, F.; Dallal, M.M.S.; Alimohammadi, M.; Foroushani, A.R.; Rajabi, Z.; Fardsanei, F.; Imeni, S.M.; Bonab, P.T. Phage therapy: Assessment of the efficacy of a bacteriophage isolated in the treatment of salmonellosis induced by Salmonella enteritidis in mice. Gastroenterol. Hepatol. Bed Bench. 2017, 10, 131-136. [PubMed] 